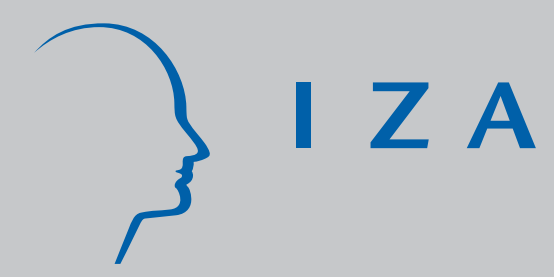

IZA DP No. 1523

Downward Wage Rigidity and Labour Mobility

Thomas Cornelißen

Olaf Hübler

March 2005 


\title{
Downward Wage Rigidity and Labour Mobility
}

\author{
Thomas Cornelißen
}

University of Hannover

\author{
Olaf Hübler
}

University of Hannover

and IZA Bonn

Discussion Paper No. 1523

March 2005

\author{
IZA \\ P.O. Box 7240 \\ 53072 Bonn \\ Germany \\ Phone: +49-228-3894-0 \\ Fax: +49-228-3894-180 \\ Email: iza@iza.org
}

\begin{abstract}
Any opinions expressed here are those of the author(s) and not those of the institute. Research disseminated by IZA may include views on policy, but the institute itself takes no institutional policy positions.

The Institute for the Study of Labor (IZA) in Bonn is a local and virtual international research center and a place of communication between science, politics and business. IZA is an independent nonprofit company supported by Deutsche Post World Net. The center is associated with the University of Bonn and offers a stimulating research environment through its research networks, research support, and visitors and doctoral programs. IZA engages in (i) original and internationally competitive research in all fields of labor economics, (ii) development of policy concepts, and (iii) dissemination of research results and concepts to the interested public.
\end{abstract}

IZA Discussion Papers often represent preliminary work and are circulated to encourage discussion. Citation of such a paper should account for its provisional character. A revised version may be available directly from the author. 


\section{ABSTRACT}

\section{Downward Wage Rigidity and Labour Mobility}

Using data from the German Socio-Economic Panel (GSOEP) effects of being individually affected by downward wage rigidity on layoffs, quits and intra-firm mobility are investigated. We measure the individual extent of wage rigidity within a structural empirical model that allows us to estimate the notional wage growth which is about $1.4 \%$ on average over the whole period. Wage growth is swept up by $3.3 \%$ through wage rigidity and $62 \%$ of the work force are in the real rigid regime. We find negative effects of wage sweep-up on quits, layoffs and promotions. This is consistent with a core-periphery view of the labour force, where a core work force is at the same time protected from layoffs and from wage cuts, whereas a peripheral work force provides a buffer for adjustment and suffers from both flexible wages and more insecure jobs. Reducing promotions for high wage sweep-up workers seems to be strategy of employers to circumvent wage rigidity. This suggests that it is not a pay policy chosen by the employer, but that it is imposed upon the employer through bargaining power. However, decreased promotion opportunities do not seem to fully outweigh the benefit of generous wage growth.

JEL Classification: J31, J63

Keywords: $\quad$ wage rigidity, wage sweep up, job mobility, quits, layoffs, promotions

Corresponding author:

Olaf Hübler

Institut für Quantitative Wirtschaftsforschung

Abteilung für Empirische Wirtschaftsforschung, insb. Ökonometrie

Universität Hannover

Königsworther Platz 1

D-30167 Hannover

Germany

Email: huebler@mbox.iqw.uni-hannover.de 


\section{Introduction}

Wage rigidity seems to be a defining characteristic of labour markets in many countries. Various studies have investigated wage rigidity and come to the conclusion that wages are not entirely flexible. Especially downward wage rigidity is of relevance, as labour market institutions and fairness standards usually define lower bounds for the wage evolution, not upper bounds. Downward wage rigidity is also a potential cause of unemployment in some labour markets.

Most studies, especially in the U.S., have studied downward rigidity in nominal wages, whereby the discussion often focused on the relation of downward nominal wage rigidity with inflation ${ }^{1}$. Indeed, downward nominal wage rigidity has important implications for the optimal rate of inflation, as the effect of the rigidity may be attenuated at higher rates of inflation (Tobin 1972).

By definition, rigidity in real wages cannot be attenuated with inflation. At the same time, the degree of downward real wage rigidity may be much stronger than that of downward nominal wage rigidity in countries such as Germany where collective bargaining plays an important role in wage setting. Empirical work supports the view that downward real wage rigidity is more important in Germany than downward nominal wage rigidity (Fehr, Goette and Pfeiffer 2002, Bauer, Bonin and Sunde 2003).

With a potentially large extent of downward real rigidity that cannot be attenuated by monetary policy, it is especially interesting to see how this affects the labour market. In this paper, we study the effect of downward nominal and real wage rigidity on mobility decisions in the labour market. Using the German Socio-Economic Panel (GSOEP), we investigate whether being individually affected by wage rigidity increases the risk of layoffs for the concerned workers. We are also interested in how wage rigidity affects quits as well as intra-firm mobility. The extent to which an individual is affected by wage rigidity is measured within an empirical model that allows us to estimate the counterfactual wage growth that would prevail in the absence of rigidities. The data set we use contains richer information on labour market mobility than the data sets that have been used before to measure wage rigidity with this methodological approach for Germany.

The paper proceeds as follows: Section 2 develops the theoretical background including potential causes of downward wage rigidity and consequences with respect to labour market

\footnotetext{
1 Downward nominal wage rigidity has been analysed by studying the features of the wage change distribution in micro data sets. While McLaughlin (1994) and Smith (2000) find a rather low degree of downward nominal wage rigidity for the U.S. and the U.K. respectively, Card \& Hyslop (1997), Kahn (1997) and Altonji and Devereux (2000) find more substantial rigidity in nominal wages in the U.S. labour market. Kramarz (2001) gives an overview over the results of different studies. For Germany, Knoppik and Beissinger (2003) and Beissinger and Knoppik (2001) find downward nominal wage rigidity in individual micro data.
} 
mobility. On this basis, hypotheses are derived. Section 3 presents prior empirical work. Section 4 describes our data. Section 5 develops the econometric model. Section 6 presents results, and section 7 concludes.

\section{Theoretical background}

\subsection{Causes of downward wage rigidity}

Theoretical foundations of downward wage rigidity must explain why wages are less responsive to negative shocks than to positive shocks. Theories that explain wage rigidity, wage stickiness or sluggish wage adjustment on the basis of menu costs, transaction costs or implicit contracts cannot explain this particular asymmetry. Traditional efficiency wage theories that link the wage level to productivity explain why wages may be above market clearing level, but they do not necessarily imply wage rigidity or more specifically downward wage rigidity. For example, even though the Shapiro-Stiglitz model links wages to productivity and explains the coexistence of above market-clearing wages and unemployment, it also implies that wages are responsive to changes in economic conditions (Shapiro and Stiglitz 1984).

More specific theoretical foundations to explain downward wage rigidity have been proposed. For the study of downward nominal wage rigidity these are theories of efficient contracting and fairness standards (Holden 2002, Elsby 2004). The efficient contracting literature is concerned with optimal employment contracts in the presence of job-specific investments and turnover costs. The rents derived from such investments drive a wedge between the outside options of the employer and of the employee. In MacLeod and Malcomson (1993) and Malcomson (1997) it is argued that a rigid wage rate reduces uncertainty about whether the other party of the contract might capture rents through bargaining power. The fixed wage rate therefore induces efficient investments into job-specific and general human capital. The wage can only stay fixed as long as neither outside option binds. Otherwise it is renegotiated. If the nominal wage rate is held constant, e.g. because indexing on prices is costly, inflation drives the real wage closer to the lower bound, the worker's outside option. Therefore, the worker's outside option is likely to bind more often. Consequently, wages are more frequently negotiated upwards after a positive shock than they are negotiated downwards after a negative shock. Downward nominal wage rigidity is observed as a result of efficient contracting. If the real wage is held constant there is symmetric real wage rigidity, but not specifically downward real wage rigidity. When looking for specific explanations for downward wage rigidity, efficient contracting is suitable for downward nominal wage rigidity only. As downward real wage rigidity is of greater importance in our context, theories other than efficient contracting seem more relevant.

Efficiency wage theories linked with fairness and reciprocity considerations seem appropriate (Akerlof 1982, Akerlof and Yellen 1988, Fehr and Gächter 2000). Workers have a judgement of a fair wage. If they are treated fairly, they offer a high productivity (or low fluctuation) in exchange. If the wage falls short of the fair wage, workers reciprocate with a low productivity (or 
high fluctuation). This version of efficiency wage theory can explain downward wage rigidity if productivity losses or turnover costs after a wage cut are stronger than the respective gains after a wage rise of equal magnitude. This may be because workers perceive wage cuts as exceptionally unfair, whereas they perceive wage rises as the norm and quickly get used to the new wage level. Workers therefore might react to wage cuts with a permanent reduction of effort, whereas they react to wage rises only with temporary increases of effort. Alternatively, wage cuts may destroy workers' allegiance with their employer and cause them to quit once the economy improves. The firm would then be reluctant to cut wages because wage cuts are overproportionately costly. Even though unemployed workers should be willing to underbid prevailing wages, employers do not accept such offers because this would undermine fairness perceptions with regard to the internal pay structure (Bewley 1999). These approaches come close to Keynes's view that downward wage rigidity is explained by employees' preoccupation with pay differentials among workers in similar jobs at different firms (Keynes 1936).

In order to explain downward nominal wage rigidity using this theory, one must assume that workers are subject to money illusion. If, instead, workers care about real wages, this theory explains downward real wage rigidity. The fact that many firms in Germany voluntarily align their wage setting to collectively bargained wage agreements (Kohaut and Schnabel 2003a) suggests that efficiency wage reasons are at least partly set in terms of real wages.

The efficiency wage and reciprocity approach explains downward wage rigidity as a result of firms' optimising behaviour given the effect of wage changes on the effort level or on the propensity to quit of workers. Downward wage rigidity of this type can be regarded as efficient.

Fehr, Goette, Pfeiffer (2002) and Pfeiffer (2003a) propose to distinguish efficient wage rigidity (e.g. the one based on efficient contracting and efficiency wages / reciprocity) from wage rigidity due to bargaining power. Workers endowed with bargaining power may prevent wage cuts, although the firm would cut wages in the absence of worker bargaining power.

Insider-outsider theory maintains that insiders have some bargaining power due to labour turnover costs or labour laws (Lindbeck and Snower 2001). Insiders who are protected from layoffs by seniority rules and employment protection legislation may withstand wage cuts in a recession. This prompts layoffs of workers who are not insiders. In a subsequent boom, insiders bargain for wage increases. This lowers the profitability of firms. They do not re-hire formerly laid off workers to the same extent. Over the business cycle, employment is reduced while wages of the employed insiders rise.

Bargaining power can be reinforced through collective bargaining systems. The union's objective function may target wages but not employment. The median voter among union members may not face an unemployment risk, either because bargained wage rises are not high enough or 
because he is protected by seniority rules. This will lead to wage bargaining with little regard to employment consequences.

Individual or collective bargaining power makes wage cuts less frequent and wage freezes or wage rises more frequent than they would be in a counterfactual flexible labour market without bargaining power. As before, the theory explains downward nominal wage rigidity if money illusion is present and downward real wage rigidity if bargaining workers care about real wages.

In reality different types of wage rigidity can coexist. To some extent wage rigidity may be an efficient labour market solution agreed upon by both parties, and to some extent it may be unilaterally enforced through bargaining power. The manager survey conducted by Franz and Pfeiffer (2003) suggests that not only efficiency wage considerations but also wage floors from collective bargaining are relevant to the German labour market and induce employers to be reluctant to cut real or nominal wages.

This leads us to the following hypothesis:

Hypothesis 1: A substantial fraction of employees in the German labour market is in wage setting regimes where the nominal or the real wage is downwardly rigid. This causes excess wage growth, 'wage sweep-up', compared to a counterfactual situation where no wage rigidity exists.

Particularly real wage rigidity appears to be relevant in the German labour market, where $85 \%$ of German employees work in firms that are directly or indirectly covered by collective bargaining agreements (Kohaut and Schnabel 2003b, Gerlach and Stephan 2004). Unions target real wages rather than nominal wages.

However, not all labour market groups are likely to be affected by wage rigidity to the same extent. The likelihood that an employee obtains a rigid wage depends on individual and firm characteristics as well as on the nature of the employment relationship.

Contract literature emphasises that fixed nominal wage contracts can induce efficient investments (MacLeod and Malcomson 1993, Malcomson 1997, Holden 2002). A larger extent of match-specific capital increases the range between the employer's and the employee's outside options. This decreases the likelihood that one of the outside options binds and that the wage is renegotiated. Wage flexibility should therefore be lower, the higher is match-specific capital, which may be measured by tenure. Some evidence is provided by Hart (2003), who finds that real wage cyclicality in the U.K. is reduced for job stayers as opposed to job movers and that it is further reduced with increasing tenure.

When rigid wages comply with fairness standards and serve to keep up morale and productivity or to reduce turnover, wage flexibility should be reduced in those employment situations where 
efficiency wages play an important role. This is the case where monitoring of workers' output is difficult due to complex tasks (higher educated workers, occupational status) or due to a large firm size. Efficiency wages are also relevant when the effect of shirking is costly, as in large firms that use capital more intensively, or when fluctuation is costly, as with employees with a high human capital endowment (tenure, education, experience). Empirical evidence in Kohaut and Schnabel (2003b) suggests that larger firms and firms with a higher share of qualified workers are in fact more likely to be covered by collective bargaining agreements.

Theories of internal labour markets suggest that wages are tied to jobs rather than to workers and that to a certain degree these wages may be independent from market fluctuations (Doeringer and Piore 1971). According to the core-periphery or dual labour market hypothesis (Saint-Paul 1996), a core workforce is sheltered by internal labour markets, while a marginal work force provides a buffer for adjustment to market fluctuations. Less skilled workers may be more likely to be part of the peripheral workforce. Finally, efficient contracting, efficiency wages and bargaining power are less relevant for employees with a high propensity to change jobs. These do not react so strongly to internal incentives. In this case wages can be expected to be relatively flexible.

Hypothesis 2: Firm size, education, tenure, work experience and occupational status are positively related to the propensity of being in a rigid regime. External job moves are negatively related to being in a rigid regime.

\subsection{The effect of wage rigidity on mobility}

In our empirical analysis, the extent of downward wage rigidity on an individual level is captured by the wage sweep-up. It measures the excess wage growth due to rigid wages in comparison to a counterfactual labour market where wages would be flexible. As the wage-employment relationship is central to the economic analysis of the labour market, it is of specific interest to ask how the extent of excess wage growth affects job mobility decisions. Two mechanisms are possible. On the one hand wage rigidity for specific workers groups may induce less mobility of these employees, while other groups have to bear the whole adjustment burden. On the other hand, individual downward wage rigidity goes hand in hand with a higher degree of job flexibility. We have to distinguish between external and internal labour mobility. The former can be due to quits and layoffs while the latter contains promotions and intra-firm transfers.

\section{Quits}

In search models, quits occur when the discounted utility stream of an alternative job or activity exceeds the discounted utility stream of the current job after mobility costs have been taken into 
account (Mortensen 1986). Wages as well as non-wage job characteristics are part of the utility associated with a job. To a worker who cares about wages, a high wage sweep-up is an advantage of his current job, as it secures a high wage level and prevents downward wage adjustments in the case of an adverse shock. Ceteris paribus, a high wage sweep-up should therefore reduce the propensity to quit. If an employee interprets the wage sweep-up as a premium to the individual earnings capacity, we should expect that the duration of his search to find a better paid job lasts longer (Gerlach and Hübler 1992) and this means that the probability to quit decreases. Those workers who are not affected by wage sweep-up do not only tend to quit because they feel that they are paid too low compared to other employees in the firm or compared to their effort level, but they may also anticipate a higher individual risk of being laid off (see discussion on wage rigidity and layoffs in the next section).

In some circumstances a high wage sweep-up may also lead to an increased labour turnover. If other firms are incompletely informed about the productivity of workers they assess high wages as signal of high productivity and poach such workers. Lazear $(1998,209)$ writes: "More often than not, the workers who are easy to steal are the ones not worth stealing. If the outside firm can outbid the worker's current employer then maybe the outsider is bidding too much."

Our hypothesis is that the stabilising effect of wage rigidity on the propensity to quit predominates.

Hypothesis 3: A higher wage sweep-up reduces the propensity to quit.

\section{Layoffs}

If firms are reluctant to cut wages because of the adverse effects on morale and productivity, they need some alternative adjustment mechanism to shocks. If nominal wages are rigid, one possible adjustment is through higher prices. Indeed, nominal wage rigidity is less of a constraint at rates of high inflation (Tobin 1972). If inflation is low, the possibility of raising prices is constrained especially if firms compete strongly in product markets. Instead of cutting pay or raising prices, firms may then prefer to adjust to negative shocks through layoffs. These do less damage to morale and productivity of the remaining workforce, because the concerned workers exit the firm. Laid off workers suffer and would like to react, but they are no longer in the firm. The threat of layoffs may even increase the productivity of those who stay in the firm (Bewley 1999).

Another explanation of positive correlation between downward wage rigidity and layoffs is that firms wait to adjust wages to economic shocks because they are uncertain whether the shock is only a transitory one. But if the employer realises that the negative consequences are longerterm they have to react with employment adjustments. 
Wage sweep-up due to employees' bargaining power (collective or individual) that has no productivity enhancing effect may also induce employers to lay workers off.

These reasons for a positive association between wage sweep-up and layoffs lead to the following hypothesis.

Hypothesis 4a: $\quad$ A higher wage sweep-up increases the risk of being laid off.

However, from a theoretical perspective, the opposing relationship cannot be ruled out.

Workers may be heterogeneous with respect to their degree of wage sweep-up. Whether or not layoffs are empirically associated with wage sweep-up will depend on whether firms lay off workers among those most affected by wage rigidity, or whether firms lay off other groups of workers. If protecting workers from wage cuts is a motivation and incentive device, it may be targeted towards certain groups of workers who are likely to acquire firm-specific human capital and who have a long-term value to the firm. When being forced to lay off personnel, firms are then unlikely to lay off those workers. They may rather lay off other types of workers. This would imply that workers protected against wage cuts or moderate wage growth by rigid wages would at the same time benefit from employment security, while other groups of workers would simultaneously suffer from higher earnings volatility and greater employment risks.

The same is true if, in the case of wage sweep-up due to bargaining power, intended layoffs of high wage sweep-up workers cannot be realised because of employment protection legislation and labour laws. Those insiders that benefit from wage rigidity may also benefit from labour legislation with respect to layoffs. In Germany, firms have to justify layoffs for economic reasons and they are bound to a social plan that stipulates social criteria in order to assess which employees of the work force are actually laid off.

Both explanations correspond to a core-periphery view of the labour force, where a core work force is at the same time protected from layoffs and from wage cuts, whereas a peripheral work force provides a buffer for adjustment and suffers from both flexible wages and more insecure jobs. The resulting hypothesis is the inverse of hypothesis $4 a$.

Hypothesis $4 b$ : A higher wage sweep-up reduces the risk of being laid off.

It may also be that there is an adverse effect of wage rigidity on employment, but no effect on layoffs of any group of workers. This is the case if firms adjust employment by reducing the hiring rate rather than increasing the separation rate. Some evidence is provided by Abowd, Corbel and Kramarz (1998) who analyse job and worker flows in a data set of French establishment between 1987 and 1990. They find that employment is adjusted by varying the 
entry rate of workers at the firm level rather than by varying the exit rate. Exit rates typically only increase when firms are shrinking by a large extent (<-20\%), whereas otherwise they stay rather constant. In contrast, the entry rate is much more clearly correlated with firm growth. For the U.S. there is also evidence that job loss rates are relatively stable, whereas job findings rates vary with the business cycle (Hall 2003, 2004).

Another adjustment strategy would be to moderate positive wage growth rates of those workers not directly affected by wage rigidity in order to make up for the excess wage growth of those workers affected. The cost of downward wage adjustments may actually not only reduce wage cuts, but may also make firms more reluctant to grant wage increases, as they know that reversals of wage increases in the future are costly (Elsby 2004). Such a compression of the wage growth distribution would not necessarily reduce employment, although one can imagine that it would distort the resource allocation in comparison with an uncompressed wage growth distribution.

\section{Promotions}

According to Lazear (1999, p. 207), promotions are characterised by a change in the job title and a wage increase whereby the actual occupation may stay the same. It follows that the productivity increase associated with a promotion, if any, may be expected to be small, especially if workers are competing intensely for the promotion and productivity is thus already high at the lower hierarchy level (Lazear 1999, p. 229). In the tournament literature the pay increase associated with promotions is interpreted as an incentive to induce higher effort levels while workers compete for promotion (Lazear and Rosen 1981). If efficiency wages and promotion tournaments are complementary personnel policies, the same groups of workers that are granted rigid wages might also be more likely to be subject to promotion. This may be high ability workers or workers with a large amount of specific human capital. Not only may employers want to prevent certain workers from wage cuts or moderate wage growth, but they may grant further wage increases, which are administered through promotions.

Hypothesis 5a: A higher wage sweep-up increases the chances of being promoted.

But we should also mention the following scenario: If workers with and workers without wage sweep-up compete with one another for promotion, the incentive for the latter is lower. This means that high wage sweep-up workers expend lower effort levels with the consequence of a lower probability of being promoted.

Employers might use positional changes to adjust wages when wages within positions are rigid (Solon, Whatley and Stevens 1997). Wage rises are realised through promotions. Wage freezes or moderate wage growth might be implemented by reducing promotion opportunities or even by 
increasing demotions or transfers. Following this line of argument, workers with a high wage sweep-up would be less likely to receive a promotion. If high wage sweep-up is due to bargaining power, say because collective bargaining agreements have settled for wage rises that exceed productivity growth for some workers, the employer's strategy may be to reduce promotion opportunities for those workers. This is especially the case if laying off the workers is not an option due to employment protection legislation or seniority rules. Therefore, in the case of bargaining power wage rigidity we expect:

Hypothesis 5b: A higher wage sweep-up reduces the chances of being promoted.

In a setting where wage rigidity is due to efficiency wage considerations, decreasing promotion activities and therefore decreasing future wage growth is not an option, because by itself it has an adverse effect on morale and productivity.

\section{Transfers of personnel}

Internal mobility may substitute for employment and wage flexibility not only by varying promotion opportunities, but also by implementing transfers of personnel. Workers who have accumulated a high wage sweep-up may be transferred to positions where they are more productive relative to their wage level or to positions where wages are less rigid. The old position may be filled with a worker who can be recruited internally or externally at a lower wage. If the new position exhibits lower or more volatile wage growth, this may also have direct adverse consequences on productivity and therefore it is questionable whether it is a feasible option when efficiency wage considerations are an important factor. A demotion might be as harmful to worker motivation as a wage cut. However, if in the new position efficiency wage considerations are a minor factor (e.g. if output can be monitored more easily or if shirking is less costly) the impact of a transfer on productivity may be less severe than that of a wage cut in the same position. In a setting where wages are rigid primarily due to bargaining power, and thus efficiency wage considerations do not play a role, aspects of motivation are less important. Adverse effects of demotions or transfers on worker productivity are then expected to be small, thus making them a possible strategy to circumvent wage rigidity.

Hypothesis 6: A higher wage sweep-up increases the likelihood of being transferred to a different job within the firm. 


\section{Prior empirical work}

The earnings function approach we use to measure wage rigidity is pioneered by Altonji and Devereux (2000) who explore downward rigidity in nominal wages for the U.S. They estimate the probability of receiving a nominal wage cut at close to zero and conclude that nominal wage rigidity is a pervasive phenomenon in the U.S. labour market. The earnings function approach has been applied to measure downward nominal wage rigidity in Switzerland (Fehr and Goette 2002), Italy (Devicienti 2003) and Germany (Knoppik and Beissinger 2003). Closer to our study are those studies that have extended the earnings function approach by also considering real wage rigidity. This has been done by Fehr, Goette and Pfeiffer (2002) and Bauer, Bonin and Sunde (2003) for Germany, by Devicienti, Maida and Sestito (2003) for Italy and by Barwell and Schweitzer (2004) for the U.K. These studies find that a more substantial fraction of the work force is affected by real wage rigidity than by nominal wage rigidity, and that wage growth is swept up more substantially by real wage rigidity than by nominal wage rigidity. Table 19 compares the results of the studies for Germany.

Further evidence on the existence of downward wage rigidity comes from experimental studies and manager surveys. Fehr and Falk (1999) conduct an experiment where they analyse the behaviour of employers and workers with respect to underbidding prevailing wages when there is unemployment. They find that in the experiment workers' effort is positively related to wages. Therefore, in a setting where the effort level of employed workers cannot be fixed in the labour contract, wage cutting is costly as workers adjust their effort levels downwards. As a result, employers in the experiment rarely accept the underbidding of wages by outside workers.

Franz and Pfeiffer (2003) conduct a manager survey in 801 German companies. They find that managers broadly say they refrain from cutting pay in order to reduce worker turnover and maintain productivity. With respect to low skilled workers, managers mention collective bargaining agreements as an additional impediment to (real) wage cuts, whereas for high skilled workers the reasons lie more in reducing turnover and recruitment costs when human capital investments are present.

In numerous interviews with managers and trade union representatives, Bewley (1999) presents qualitative evidence on the reluctance of managers to cut pay. Managers in the U.S. clearly fear adverse effects of pay cuts on morale and productivity and therefore avoid pay cuts, in some cases relying on layoffs instead.

Whether such a suggested effect of wage rigidity on unemployment and mobility can be established in micro data, has been explored by most of the studies that have used the earnings function approach to measure wage rigidity. 
Altonji and Devereux (2000) investigate real effects of nominal rigidity on layoffs, quits and promotions with several panels and two methods to deal with the problem of unobserved heterogeneity. The results depend on the applied method. They estimate separate linear probability models for the probability of a quit, a layoff and a promotion. The coefficients of wage rigidity in the quit function are always negative, though not always significant, while in the layoff and promotion functions they are generally insignificant and the signs are mixed.

Fehr and Goette (2002) demonstrate with data from Switzerland that the wage sweep-up induced by wage rigidity is strongly correlated to unemployment. This relation holds if the inflation rate is also incorporated into the unemployment function. The authors compute these indicators for every canton and every industry. The higher the degree of wage rigidity, the higher the unemployment rate.

Pfeiffer (2003a, ch. 7.2), based on the model estimated in Fehr, Goette and Pfeiffer (2002), uses the individual wage sweep-up to explain wage growth, individual unemployment, external job moves and the evolution of the firm size in later periods. At the sectoral level, he estimates the effect of the average wage sweep-up on employment growth (Pfeiffer 2003a, ch. 7.3). At the individual level, he finds that wage growth is not moderated by a high wage sweep-up, that the unemployment risk is not increased, but rather decreased, and that external job changes become less likely with a higher wage sweep-up ${ }^{2}$. There seem to be no adverse consequences for those workers affected by wage rigidity. However, a high wage sweep-up seems to be linked to declining employment at the firm level and to attenuated employment growth at the sectoral level. Pfeiffer (2003a, p. 266) therefore concludes that wage rigidity does not have adverse effects on those workers directly affected by the rigidity, but on others whose wages are flexible.

Bauer, Bonin and Sunde (2003) find that the aggregate wage sweep-up, especially the part due to real wage rigidity, seems to increase aggregate unemployment growth after two periods. However, they are cautious to interpret this result too strongly, as their analysis on the aggregate level may hide what is going on at the micro level.

Devicienti, Maida and Sestito (2003) estimate the effect of the wage sweep-up at the macro level in a Phillips curve framework that they parameterise by choosing parameter values from the literature. This leads to the finding that the increased wage growth due to nominal and real wage rigidity raises the NAIRU by 6 - 7.5 percentage points in Italy (at an average unemployment rate of $10.4 \%)$.

\footnotetext{
2 The relationship between the wage sweep-up and plant mobility is not uniform over the entire considered period 1976-1990. The coefficients are negatively significant with the exception of the period 1980 to 1984 .
} 


\section{The data}

We use data from the German Socio-Economic panel (GSOEP) household survey that contains a rich set of socio-economic variables. Our data cover the period from $1984-2003$. An overview of the structure of the GSOEP is provided by Haisken-DeNew and Frick (2003).

We restrict our sample to employed workers between 16 and 65 years of age, for whom data on wages is available for at least two consecutive years. We drop observations where monthly wages are below $250 €$. The GSOEP states the gross wage of the month prior to the interview, including overtime payment. Different measures of working hours are available. We use contractual working hours and overtime hours referring to the month prior to the interview. Overtime hours include paid and unpaid overtime. However, the information in most of the waves of the GSOEP does not allow the separation of overtime into the number of hours that are paid and those that are unpaid. Contractual working time and overtime are stated as weekly hours. We multiply weekly hours by four in order to construct monthly hours.

We construct hourly wages by dividing the monthly gross wage by the sum of monthly contractual hours and overtime. This measures labour costs more appropriately than if only the contractual working hours were considered. Through the variation of overtime work firms may gain some wage flexibility that would not show up in a measure of hourly wages that just accounted for contractual working time ${ }^{3}$.

We capture wage growth by taking the difference in the log wage for all wage observations that are available in two consecutive years. We trim the wage change distribution by dropping observations with absolute wage changes of more than $0.5 \log$ points, thereby removing $4 \%$ of the observations, assuming that growth rates larger than $50 \%$ are not correctly measured. Missing values of regressors included further reduce the sample size. Besides regressors from the GSOEP, we also match external information to our data set. These are the annual inflation and unemployment rate as well as data on collectively bargained wage growth. The inflation rate is constructed from the consumer price index of the German Federal Statistical Office 4. Unemployment rates for East and West Germany are published by the German Federal Labour

\footnotetext{
${ }^{3}$ The overtime premium usually exceeds the hourly base wage. When paid overtime work is increased, overtime pay constitutes a larger fraction of total compensation, thus increasing the average hourly compensation. An expansion of unpaid overtime, however, decreases the average hourly compensation.

4 The consumer price index is available on-line in the "prices" section of the German Federal Statistical Office homepage, http://www.destatis.de/themen/e/thm preise.htm, link accessed on 30 ${ }^{\text {th }}$ September 2004.
} 
Office $^{5}$. The index of collectively bargained wages is published by the German Federal Statistical Office. It is not available for all sectors. Notably the service sector is missing, so that our analysis will largely exclude this sector ${ }^{6}$. Furthermore, from our data source the index is only available up to 2002, and for East Germany only from 1995. When constructing collectively bargained wage growth rates a further year is lost. East German observations thus only enter our analysis from 1996 onwards. Finally, over the 18 wage change periods from 1984 to 2002 we have 36944 observations when estimating the rigidity model.

The GSOEP survey includes retrospective questions on job mobility. The construction of the job mobility variables from these questions, as well as some descriptive statistics on job mobility in our sample are included in appendix B. Appendix A contains the full set of variables from our analysis with descriptive statistics.

The data set has strengths as weaknesses for the present purpose. Using a household survey as opposed to administrative data is less appropriate for measuring wage rigidity for two reasons. Firstly, household surveys usually provide smaller sample sizes than data sets that are provided by the social security or fiscal administration. If one intends to measure wage rigidity within a structural model that identifies a large set of parameters simultaneously, the sample size clearly matters. With our data set, we do not have much scope to estimate the model in subsamples. Secondly, household surveys are more prone to measurement error than registry data from official sources. This makes the estimation of wage growth rates, that takes place within the structural model presented in the next section, less precise, although it is possible to take measurement error into account when formulating the model.

There are also benefits from using household survey data. The available regressors are much richer with respect to socio-economic, demographic and work-place related information. While administrative data may provide very accurately measured data on wages, quite often variables of particular interest are missing. For example, comparing the GSOEP survey to the German IAB employment sub-sample (IABS, Beschäftigtenstichprobe), the GSOEP has more detailed information on hours worked, human capital and job mobility. In fact, the IABS lacks information on hours worked. Only the broad categories full- and part-time are reported, and changes between the two within a given year are not registered. Furthermore, earnings data are right

\footnotetext{
${ }^{5}$ Monthly and yearly unemployment data by region is available at the German Federal Labour Office on-line at http://www.pub.arbeitsamt.de/hst/services/statistik/aktuell/iiia4/zr alo qu west ostb.xls, link accessed on $25^{\text {th }}$ September 2004.

${ }^{6}$ The data is taken from the German Federal Statistical Office STATIS time series data base, segments 4031, 4033, 4037, 4039, 4055 and 4057. There are three indices on collectively bargained wage growth, referring to hourly wages, weekly wages and salaries. From these we construct the average growth rate per sector, gender and region, as the data is provided along these dimensions and we match it along these dimensions to the GSOEP.
} 
censored, as wages are only recorded up to the social security contribution ceiling. This reduces some of the alleged accuracy of the IABS. Job changes and job separations can be identified in the IABS, but the reason for the separation is unknown. In the GSOEP, we can identify quits, layoffs and other separations separately, as well as internal job moves with the same employer. Job mobility being in the focus of our analysis means we would not be able to conduct our analysis with the IABS, as desirable as a larger sample size and more accurate data would be.

\section{The econometric model and estimation issues}

We estimate the extent of wage rigidity using the earnings function approach introduced by Altonji and Devereux (2000). This approach models the observed wage change through

(i) an underlying notional wage change that is the wage change which would prevail in absence of wage rigidity,

(ii) the effect of downward wage rigidity, and

(iii) the effect of measurement error.

The notional wage change, the rigidity parameters and the extent of measurement error are simultaneously estimated in a structural model of wage rigidity by a maximum likelihood method $^{7}$.

The model we use is similar to the one devised by Dickens and Goette (2002), which represents a generalisation of the original Altonji-Devereux model in that it incorporates not only downward nominal wage rigidity, but also downward real wage rigidity. This model was implemented in German, Italian and British data sets by Bauer, Bonin and Sunde (2003), Devicienti (2003), Barwell and Schweitzer (2004) respectively.

The notional wage change $w_{i t}^{*}$ for individual $i$ at time $t$ depends on a set of covariates $x_{i t}$,

$w_{i t}^{*}=x_{i t}^{\prime} \beta+e_{i t} \quad e_{i t} \sim N\left(0, \sigma_{e}^{2}\right)$

where $\beta$ is a coefficient vector and $e_{i t}$ the error term.

Following Barwell and Schweitzer (2004), we allow for the error term to be heteroscedastic. Its standard deviation depends on a vector $s_{i t}$ of individual characteristics as follows,

$\sigma_{e, i t}=\exp \left(s_{i t}^{\prime} \alpha\right)+e_{\sigma e, i t}$

where $\alpha$ is the corresponding coefficient vector and $e_{\sigma e, i t}$ is an error term satisfying classical assumptions. The exponential function transformation assures positive estimates of the standard deviation.

\footnotetext{
${ }^{7}$ As we will set out, we do not follow the original approach completely. We have decided to estimate some of the parameters outside the model, because we expect to be able to obtain more precise estimates.
} 
Thus we account for the different volatility of wage growth faced by individuals based on their individual characteristics.

Whether or not an individual actually receives her notional wage change depends on whether the wage is set in a rigid wage setting regime, and whether wage setting within this regime is constrained or not. There are three wage setting regimes, a flexible, a nominal rigid regime and a real rigid regime.

In the flexible wage setting regime, the actual wage change of the worker, $w_{i t}^{a}$, always equals the notional wage change:

$w_{i t}^{a}=x_{i t}^{\prime} \beta+e_{i t}$

In the two rigid regimes, the actual wage changes equals the notional wage change only if the notional wage change exceeds a certain threshold value. Otherwise, the actual wage change is constrained to the threshold value. In the nominal rigid regime the rigidity threshold is zero, while in the real rigid regime it is a positive threshold value $r_{i t}$.

Formally, wage setting in the nominal rigid regime is then characterised by

$$
\begin{aligned}
w_{i t}^{a} & =x_{i t}^{\prime} \beta+e_{i t} & & \text { if } \quad x_{i t}^{\prime} \beta+e_{i t}>0 \\
& =0 & & \text { otherwise }
\end{aligned}
$$

and in the real rigid regime by

$$
\begin{aligned}
w_{i t}^{a} & =x_{i t}^{\prime} \beta+e_{i t} & & \text { if } \quad x_{i t}^{\prime} \beta+e_{i t}>r_{i t} \\
& =r_{i t} & & \text { otherwise }
\end{aligned}
$$

The rigid regimes are tobit models where the distribution is left censored at the respective rigidity threshold. The probability mass from below the threshold value is entirely shifted to a mass point at the threshold value.

In the original model devised by Dickens and Goette (2002), the real rigidity threshold $r_{i t}$ is estimated along with the other coefficients of the model. Our version of the model is different in that $r_{i t}$ is provided as data in the form of the collectively bargained wage growth. Providing the rigidity threshold as data gives more structure to the estimation and reduces the parameter space. We believe that it is adequate to equal the real rigidity threshold to the collectively bargained wage growth, because in Germany a large share of employees are covered by collective bargaining agreements and when real wage rigidity occurs it is most probably mediated by collectively bargained wage growth ${ }^{8}$.

\footnotetext{
${ }^{8}$ Fehr, Goette and Pfeiffer (2002) proceed in the same way.
} 
So far we have modelled the actual wage change depending on the notional wage change and the effect of downward real and nominal wage rigidity. However, the observed wage change is likely to differ from the notional wage change not only because of wage rigidity, but also because of measurement error (misreporting), a problem that is likely to be prevalent in our data set. First we assume that there is only one type of uniform measurement error for all observations. The observed wage change, $w_{i t}^{o}$, is then the actual wage change plus measurement error.

$$
w_{i t}^{o}=w_{i t}^{a}+m_{i t} \quad m_{i t} \sim N\left(0, \sigma_{m}\right)
$$

We assume that $m_{i t}$ is independent of $e_{i t}$. As with the error term of the notional wage growth equation, we allow for the standard deviation of measurement error to vary with individual characteristics. The rationale is that some groups of individuals report wages more accurately than others. The standard deviation of the error term is modelled as

$$
\sigma_{m, i t}=\exp \left(t_{i t}^{\prime} \gamma\right)+e_{\sigma m, i t}
$$

where $t_{i t}$ is a vector of explanatory variables that can be thought of as being linked to the accuracy of reporting wages in a household survey, $\gamma$ is the corresponding coefficient vector, and $e_{\sigma m, i t}$ is an error term satisfying classical assumptions. The exponential function transformation assures positive estimates of the standard deviation.

With the measurement error term added to all observations, the three regimes in terms of the observed wage growth become:

$$
w_{i t}^{0}=x_{i t}^{\prime} \beta+e_{i t}+m_{i t}
$$

for the flexible wage setting regime,

$$
\begin{aligned}
w_{i t}^{o} & =x_{i t}^{\prime} \beta+e_{i t}+m_{i t} & & \text { if } x_{i t}^{\prime} \beta+e_{i t}>0 \\
& =m_{i t} & & \text { otherwise }
\end{aligned}
$$

for the nominal rigid regime, and

$$
\begin{aligned}
w_{i t}^{o} & =x_{i t}^{\prime} \beta+e_{i t}+m_{i t} & & \text { if } x_{i t}^{\prime} \beta+e_{i t}>r_{i t} \\
& =r_{i t}+m_{i t} & & \text { otherwise }
\end{aligned}
$$

for the real rigid regime.

We model a mixed measurement error. Instead of adding the measurement error term uniformly to all observations, we only do so for individuals that have reported a rounded value of the wage level in either of two consecutive periods, while treating individuals that have not rounded their wage levels in any of two consecutive periods as error free (i.e. according to equations (3)-(5)) ${ }^{9}$.

\footnotetext{
${ }^{9}$ Our treatment of mixed measurement error differs from the studies that have used the earnings function approach. Most studies assume that an observation is measured exactly with probability $q$ and affected by measurement error with probability $(1-q)$. Each observation is then treated with weight $q$ as if it were error free (i.e. according to equations
} 
With this definition $92.9 \%$ of the observations fall into the measurement error regime, the remaining $7.1 \%$ into the regime without measurement error.

Other than generally stretching out the variance of the error term that is added to the expected notional wage growth, the inclusion of the measurement error term transforms the censoring point in the rigid regimes into a normally distributed "censoring cluster". Even if notional wage growth falls short of the rigidity threshold, and actual wage growth is consequently constrained at the threshold value, we can still observe values of wage growth clustered around the threshold value, due to measurement error. The model with measurement error is therefore able to interpret not only observations at the rigidity threshold itself, but also observations clustered around the rigidity threshold as being the outcome of constrained wage setting within a rigid regime.

In order to complete the model, we have to account for the individual propensities, $p^{R}, p^{N}$ and $p^{F}$, of falling into the real rigid, nominal rigid and flexible regime respectively. These parameters are made dependent on explanatory variables (see hypothesis 3 ). The propensity of being in the real rigid regime is modelled as

$$
p_{i t}^{R}=F\left(z_{i t}^{\prime} \lambda\right)+e_{p r, i t}
$$

where $z_{i t}$ is a vector of explanatory variables, $\lambda$ is the corresponding coefficient vector, $e_{p r, i t}$ is an error term satisfying classical assumptions and $F(\cdot)$ is the cumulative distribution function (cdf) of the logistic distribution. The transformation with the cdf restricts estimates of the propensity to the interval $(0,1)$. If $p^{R}$ is determined, only one further parameter needs to be estimated, because individuals must be in exactly one of the regimes at a time. We estimate the propensity of being in the flexible regime under the condition of not being in the real regime,

$$
p_{i t}^{F \mid \bar{R}}=F\left(l_{i t}^{\prime} \varpi\right)+e_{p F \mid \bar{R}, i t}
$$

where $l_{i t}$ is a vector of explanatory variables, $\varpi$ is the corresponding coefficient vector, $e_{p F \mid \bar{R}}$ is an error term satisfying classical assumptions and $F(\cdot)$ is the cumulative distribution function of the logistic distribution.

We can derive the parameters $p^{F}$ and $p^{N}$ as follows:

$$
p^{F}=\left(1-p^{R}\right) \cdot p_{i t}^{F \mid \bar{R}}
$$

and

$$
p^{N}=\left(1-p^{R}\right) \cdot\left(1-p_{i t}^{F \mid \bar{R}}\right)
$$

(3) - (5)) and with weight $(1-q)$ as if it were measured with error (i.e. according to equations (8) - (10)). The parameter $q$ is then be estimated within the model along with the other parameters. 
The model parameters $\beta, \alpha, \gamma, \lambda, \varpi$, as well as the standard deviations of the error terms, can be estimated simultaneously by maximum likelihood, given data on the observed individual characteristics $x_{i t}, r_{i t}, s_{i t}, t_{i t}, z_{i t}$, as well as the dependent variable $w_{i t}^{o}$. The likelihood function is described in appendix $\mathrm{C}$.

However, in view of this relatively large number of parameters, and given the difficulties that usually arise when explaining wage growth rates as opposed to wage levels, it is questionable whether our data set is rich and large enough to identify the parameters simultaneously. In fact, we encountered numerical problems when trying to identify all parameters simultaneously. We therefore adopted the approach of estimating the notional wage growth equation (1) partly outside the model by quantile regression, following Barwell and Schweitzer (2004).

A quantile regression estimates a conditional percentile of the distribution of the explanatory variable, just as an ordinary regression estimates the conditional mean. The estimation of a quantile regression involves minimising a weighted sum of absolute deviations. An overview of this technique is given by Koenker and Hallock (2001). While an OLS regression that does not take into account the existence of wage rigidities is biased, it can be argued that a quantile regression is less biased if it estimates the notional wage change at a high percentile that is less likely to be affected by downward wage rigidity. In an empirical example, Buchinsky (1998) generates pseudo-data by censoring wage data taken from a real data-set. He then applies quantile regression on both the real and the artificially censored data. For quantiles farther in the non-censored side of the distribution, the estimates do not differ much between the real data and the censored data, whereas for quantiles more likely to be affected by censoring the difference is large, indicating a strong bias.

Despite choosing a high percentile, the quantile regression will not be entirely unbiased. The correct procedure of estimating a quantile regression when censoring is present would be to use censored quantile regression (Buchinsky 1998), which is not an option here, because it would only be possible within the full model because the censoring points are conditional on the wage setting regime. Therefore we deliberately chose not to estimate the notional wage growth equation within the model. With the quantile regression being less biased than OLS and more biased than censored (quantile or conditional mean) regression within the full model, we see the quantile regression of the notional wage change as a second best alternative that we adopt in order to be able to estimate a richer set of parameters in the second step: the maximum likelihood estimation of the rigidity model. 
We choose the $75^{\text {th }}$ percentile as a trade-off between a low probability of being affected by downward wage rigidity and not being too high in the tails of the distribution, because the latter would mean that the estimation is highly affected by extreme errors.

In the measurement of the extent of wage rigidity, the parameter of interest is expected notional wage growth. Whereas in the original model of Dickens and Goette (2002) this is estimated as $\hat{E}\left[w_{i t}^{*}\right]=x_{i t}^{\prime} \hat{\beta}$ by maximum likelihood within the model, in our estimation we use $\hat{E}\left[w_{i t}^{*}\right]=\widehat{p 75}-z_{0.75} \cdot \widehat{\sigma_{e}}$. The estimate of the $75^{\text {th }}$ percentile of the notional wage change, $\mathrm{p} 75$, is fed into the wage rigidity model from the quantile regression. The standard deviation of notional wage growth is estimated within the wage rigidity model alongside with the rigidity parameters by maximum likelihood (see appendix $\mathrm{C}$ for details of the likelihood function).

For the maximum likelihood estimation we proceed in two steps. In the first step, we estimate the model with only a flexible and a real rigid regime, excluding the nominal rigid regime by constraining $p^{N}$ to zero. We thus determine the individual propensity to be in a real rigid regime, $p^{R}$. In the second step, we add the nominal rigid regime, keeping $p^{R}$ from the first stage constant and estimating the other regime propensities and parameters. This procedure helps to separate real and nominal rigidity more clearly, which is difficult in a simultaneous estimation of both types of rigidity, given that the rigidity thresholds (zero and $r_{i t}$, which equals on average 0.031 ) differ by less than two thirds of the estimated standard deviation of measurement error (the estimate of $\sigma_{m}$ equals 0.053 on average). The methodology of dropping the nominal regime in the first step arguably influences the results, as it attributes a larger part of wage rigidity to the real rigid regime than in a simultaneous determination. However, proceeding in this way is not arbitrary, because we make use of a priori knowledge we have on wage setting in Germany. Collective bargaining covers $85 \%$ of German employees (Kohaut and Schnabel 2003b, Gerlach and Stephan 2004) and wage rigidity in Germany seems to be in most parts due to real wage rigidity (Pfeiffer 2003a, Bauer, Bonin and Sunde 2003).

Once notional wage growth and the other model parameters are estimated, we can determine expected actual wage growth as well as the wage sweep-up, which is the difference between expected actual wage growth and notional wage growth:

$$
s u_{i t}=E\left[w_{i t}^{a}-w_{i t}^{*}\right]
$$

We also decompose the wage sweep-up into the part due to real wage rigidity and the part due to nominal wage rigidity. 
$s u_{i t}^{\text {real }}=E\left[w_{i t}^{a}-w_{i t}^{*} \mid\right.$ real rigid regime $] \cdot p_{i t}^{R}$

$s u_{i t}^{\text {nominal }}=E\left[w_{i t}^{a}-w_{i t}^{*} \mid\right.$ nominal rigid regime $] \cdot p_{i t}^{N}$

Being in a rigid regime does not necessarily mean that wage setting is actually constrained within the regime, i.e. that an individual is affected by wage rigidity. The probability of being affected by nominal or real wage rigidity is the product of the probability of being in the respective regime and the probability that notional wage growth falls short of the respective rigidity threshold:

${\varpi_{i t}^{\text {real }}}^{\text {re }} p_{i t}^{R} \cdot \Phi\left(\frac{r_{i t}-w_{i t}^{*}}{\sigma_{e}}\right)$

$\varpi_{i t}^{\text {nominal }}=p_{i t}^{N} \cdot \Phi\left(\frac{-w_{i t}^{*}}{\sigma_{e}}\right)$

The fractions of individuals affected by nominal and real wage rigidity are estimated by averaging the estimated probabilities over all individuals.

The subsequent analysis of mobility effects consists of probit regressions of quits, layoffs, promotions and transfers on the wage sweep-up and other control variables. In the job mobility regressions, as before in the estimation of the wage rigidity model, we allow for heteroscedasticity.

Let $y_{i t}$ be a binary outcome variable that takes on the value 1 if job mobility of individual $i$ takes place at time $t$, and the value 0 if no job mobility takes place. We apply a multiplicative heteroscedastic probit model, where the expected probability of a job mobility event is

$\mathrm{P}\left(y_{i t}=1\right)=\Phi\left\{\frac{x_{i t}^{\prime} \beta}{\exp \left(z_{i t}^{\prime} \gamma\right)}\right\}$,

where $x_{i t}$ and $z_{i t}$ are vectors of covariates influencing respectively the mean and standard deviation of the latent variable underlying the probit model, $\beta$ and $\gamma$ are the related coefficient vectors, and $\Phi(\cdot)$ is the standard normal cumulative distribution function ${ }^{10}$. For regressors $w_{k}$ that are elements of both, $x$ and $z$, marginal effects of $w_{k}$ on $P\left(y_{i t}=1\right)$ depend on $\beta_{k}$ and $\gamma_{k}$ as well as on the linear combinations $x^{\prime} \beta$ and $z^{\prime} \gamma($ Greene 2003, p. 680):

$$
\frac{\partial \operatorname{Prob}(Y=1 \mid \mathbf{x}, \mathbf{z})}{\partial \mathrm{w}_{\mathrm{k}}}=\phi\left[\frac{\mathbf{x}^{\prime} \boldsymbol{\beta}}{\exp \left(\mathbf{z}^{\prime} \boldsymbol{\gamma}\right)}\right] \frac{\beta_{k}-\left(\mathbf{x}^{\prime} \boldsymbol{\beta}\right)}{\exp \left(\mathbf{z}^{\prime} \boldsymbol{\gamma}\right)}
$$

Therefore, for regressors that are element of $x$ and $z$, the sign of the coefficient $\beta_{k}$ does not necessarily equal the sign of the marginal effect.

\footnotetext{
${ }^{10}$ Note that the covariate and coefficient vectors $x, z, \beta$ and $\gamma$ in the mobility analysis are not the same as in the wage rigidity model.
} 


\section{Results}

\subsection{The extent of wage rigidity}

Table 3 reports results of the quantile regression of notional wage growth. The goodness of fit is low with a pseudo $R^{2}$ of 0.025 , reflecting the difficulties of predicting wage growth rates as opposed to wage levels. As the theoretical foundation for the interpretation of the determinants of wage growth is somewhat scarce, not all the coefficients are interpreted in detail.

Notional wage growth is faster for men and it decreases with years of schooling as well as with tenure. The influence of experience is mostly statistically insignificant, but coefficient signs indicate notional wage growth decreasing with experience. Also judging from the sign of a nonsignificant coefficient, notional wage growth decreases with the number of months of unemployment in the preceding year. Notional wage growth further decreases with overtime (including paid and unpaid overtime). This may represent decreasing returns to overtime working. Although the wage level increases with overtime work, its pace of growth decreases.

Notional wage growth increases with firm size. It also increases with occupational status and for individuals who have had vocational training in the preceding year. Notional wage growth is higher in the east (significant) and tends to be lower in the south (insignificant) of Germany, the north being the reference group. This may reflect a catching-up of the regions with lower wage levels (east and north Germany). Macro variables also affect notional wage growth. The unemployment rate as well as its values lagged one and two times affect notional wage growth negatively, suggesting that notional wage growth is responsive to macro-economic conditions. Inflation lagged by one period increases (nominal) notional wage growth, while the coefficients on current inflation and lagged inflation have a negative sign.

Only few industry dummies have a significant impact on notional wage growth. Between 1998 and 2002 notional wage growth was significantly lower, and between 1991 and 1997 it was significantly higher than in the reference period of 1985 to 1990. A dummy variable for the year 2002 is included in order to pick up effects from the conversion of wages into Euros which, via rounding behaviour, may affect the wage growth rate in that year.

Table 4 reports the ML estimates of the complete model. As the equations of the standard deviations and of the regime propensities involve non-linear transformations ( see equations (2), (7), (11), (12) ), the coefficients cannot be interpreted as marginal effects, but their signs and significance can be assessed. Panel (a) of Table 4 reports the results of the first stage estimation, where the nominal rigid regime is suppressed ( $p^{N}$ constrained to zero) and the propensity of being in the real rigid regime, $p^{R}$, is estimated. Panel (b) of Table 4 reports the second stage estimation, where the propensity of being in the real rigid regime, $p^{R}$, is held fixed 
at the level estimated in stage one and the propensities of the two other regimes as well as the other model parameters are estimated.

We explicitly model the existence of heteroscedasticity and find that there are statistically significant coefficients in the equation of the standard deviation of notional wage growth. Furthermore, within-group correlation of the error term may be present. Both of these problems bias estimated standard errors of coefficients and consequently flaw hypothesis testing. The bias from within group correlation of the error term is magnified if macro variables are matched to micro data at the group level (Moulton 1990). We have matched the unemployment and inflation rates at year level and the data on collectively bargained wages at industry level. We take these problems into account by reporting standard errors robust to heteroscedasticity as well as standard errors adjusted for clustering on industry and year.

The standard deviation of notional wage growth ( see $\sigma_{e}$ equation of panels (a) and (b) in Table 4 ) declines with age and education. This may be because young workers and less educated workers are more likely to change employers or job assignments for the reason of job-shopping, that is to say to find a job that matches their qualifications well (Johnson 1978). As young workers may be potentially more productive, there can also be a higher dispersion in their chosen effort levels. This is associated with more volatile wage growth.

The standard deviation of notional wage growth is also significantly lower for job stayers. This may be because for job movers there can be substantial returns to moving jobs, but also important wage losses after an unemployment spell.

Public sector workers also have a significantly lower volatility of notional wage growth, which seems plausible as the public sector is more shielded from competition and product demand fluctuations. For workers at a higher hierarchy level notional wage growth is also less volatile, though the association is not entirely monotonically.

There is some evidence that the standard deviation of the measurement error ( see $\sigma_{m}$ equation of panels (a) and (b) in Table 4 ) declines with education and that it increases for workers of the highest hierarchy level, although these influences are not statistically significant. The increase of the error variance of observations that have reported wages as multiples of 100 and 1000 in at least one of two consecutive periods is highly significant, lending support to our procedure of linking rounding to the incidence of measurement error when modelling the mixed measurement error.

The propensity to be in a real rigid regime ( see $p^{R}$ equation of panel (a) in Table 4 ) is significantly lower for men and there is a tendency for it to decline with potential labour market experience although this last effect is not significant. Education, tenure and public sector affiliation (all three significant) contribute positively to being in the real rigid regime, partly 
confirming our hypothesis 2 . Only one firm size dummy has a significant coefficient, which suggests that workers in firms of a higher size (200 - 2000 employees) are more likely to be in a real rigid regime than workers in the reference group (in firms of $<20$ employees). Occupational status is not significant. Judging from the sign of the coefficient, having received a promotion in the preceding year increases the likelihood of being in a rigid regime. Being transferred internally, separating after the end of a contract as well as separating "for other reasons" and quitting significantly reduce the likelihood of being in the real rigid regime. The coefficients of separating after a firm closure and after being laid off are negative as well but not statistically significant. A positive significant coefficient on nominal GDP growth indicates that the coverage of the real rigid wage setting regime is cyclical. In downturns workers may be more prepared to accept flexible wages. Firms that voluntarily set wages according to collective bargaining agreements may then refrain from doing so. Covered firms can also moderate the growth of effective wages if they reduce pay components that are not mandatory under the collective contract and thus reduce the 'effective coverage'.

Some of these results correspond to what has been found by other studies. Pfeiffer (2003a, table 6.5) reports that the propensity of wages being set in a collective bargaining regime (similar to our real rigid regime) rises with tenure and that it is higher for women and lower for individuals without formal education. It is also lower for plant movers compared to stayers (Pfeiffer 2003a, table 6.3). However, our analysis does not reveal the positive association of firm size found by Pfeiffer (2003a, table 6.5).

The lower part of panel (b) in Table 4 reports the relative propensity of being in the flexible regime rather than in the nominal rigid regime, conditional on not being in the real regime $\left(p^{F \mid \bar{R}}\right.$ equation). Here, in contrast to the equation of the propensity of the real rigid regime, a positive coefficient implies less rigidity. When specifying this equation with individual characteristics similar to the equation of the propensity of the real rigid regime, the regressors turn out not to be significant. It seems to be difficult to explain the discrimination between the nominally rigid and the flexible regime with the observed individual characteristics. We therefore opt for a specification with sector dummies. The sector structure can be expected to bundle together a set of characteristics that are otherwise not observed. In order to assess cyclical fluctuations we also include nominal GDP growth as a regressor. Conditional on not being in the real rigid regime, manufacturing, resource processing and services tend more strongly than the reference group 'retail' does towards the nominal rigid regime. If not in the real rigid regime, the mining and the credit and insurance sector tend more strongly than the reference group does towards the flexible wage setting regime. The negative coefficient of nominal GDP growth is significant at the $10-\%-l e v e l$ and indicates that, conditional on not being in the real rigid regime, upturns tend to reinforce the nominal rigid regime, while during downturns the flexible regime gains importance. 
Panel (a) of Table 5 gives an overview of the average parameter values predicted by our model in the full estimation sample. Notional wage growth averages $1.4 \%$ over the whole period, whereas expected actual wage growth averages $4.7 \%{ }^{11}$. Accordingly, there is an average annual wage sweep-up of $3.3 \%$, which is the estimate of annual excess wage growth due to wage rigidity ${ }^{12}$. Wage setting is flexible for $52.4 \%$ of the work force. This confirms our hypothesis 1 , which states that there is a substantial extent of wage rigidity with a non-negligible effect on wage growth.

The aggregate wage sweep-up is practically in its entirety due to real wage rigidity $\left(s \hat{u}^{\text {real }}=3.25 \%\right.$, sú $\hat{u}^{\text {nominal }}=0.05 \%$ ). The importance of real wage rigidity as opposed to nominal wage rigidity is also reflected by the regime propensities, which are $47 \%$ for the real rigid regime and $0.6 \%$ for the nominal rigid regime. While these propensities show the weight of the different wage setting regimes, they do not reveal the proportion of workers actually affected by nominal and real wage rigidity, in the sense that their wage setting is actually constrained in the regime, because notional wage growth falls short of the rigidity threshold. We estimate that on average $25.9 \%$ of the workforce are affected by real wage rigidity and $0.3 \%$ by nominal wage rigidity.

Table 19 compares our results to other studies that have measured the extent of wage rigidity in Germany using the earnings function approach. Pfeiffer (2003a) reports a considerably lower notional wage growth. An unweighted average of notional wage growth reported in figure 6.6 in Pfeiffer (2003a) amounts to $-0.3 \%$. He also reports a higher fraction of workers in a real rigid regime of around $70 \%$ (p. 204) and a higher wage sweep-up of around $6 \%$ (p. 201) for plant stayers during the observation period of 1976-1995. Pfeiffer's (2003a) results also show a clear prevalence of the real rigid regime. Up to $50 \%$ of plant stayers are on average affected by real wage rigidity and up to $10 \%$ by nominal wage rigidity (p. 201).

Bauer, Bonin and Sunde (2003) report a wage sweep-up for plant stayers that declines from $3.3 \%$ to $1 \%$ between 1976 and 1997 and where the part due to nominal wage rigidity is approximately constant at $0.3 \%$. Their estimated notional wage growth amounts on average to $2.4 \%$. Whereas the fraction of workers affected by nominal wage rigidity fluctuates around $6 \%$, the fraction affected by real wage rigidity exhibits a declining trend from around $40 \%$ in 1976 to around $16 \%$ in 1997.

\footnotetext{
${ }^{11}$ Wage growth rates and wage sweep-up are measured as differences in logarithms of the wage level.

${ }^{12}$ Expected average wage growth (the mean of predicted wage growth) exceeds the mean of observed wage growth. The model does not have the property that both must be equal, as would be the case in for example the classical linear regression model.
} 
Knoppik and Beissinger (2003) model nominal wage rigidity only. They report a fraction of workers actually affected as nominal wage rigidity binds of around 5.6-7.3\%, which is comparable to the values reported by Pfeiffer (2003a) and Bauer, Bonin and Sunde (2003). The resulting wage sweep-up due to nominal wage rigidity during the observation period 1976-1995, however, is much smaller $(0.08-0.12)$ in Knoppik and Beissinger (2003) than in the other studies and more comparable to our results.

In what follows, we focus some attention on the estimates of notional wage growth and of the propensity to be in a real rigid regime. Interpreting our measure of notional wage growth of $1.4 \%$ and the corresponding wage sweep-up of $3.4 \%$ literally implies that wages would have grown on average by 3 percentage points less each year over the period from 1984 to 2002, had the labour market efficiently responded to economic conditions. According to Pfeiffer's results, average wage growth would have been negative in a number of years (Pfeiffer 2003a, fig. 6.6) and wages would have grown on average by 6 percentage points less in a flexible labour market (Pfeiffer 2003a, p. 201). These are very strong claims. Actually, estimates of notional wage growth (of the wage sweep-up) of the studies mentioned, including our own, may be biased downwards (upwards), because the assumption underlying the earnings function approach, that downward wage rigidity affects the wage growth distribution only in the parts below the respective rigidity thresholds but not above, may not hold. As derived by Elsby (2004) in an explicit model of downward nominal wage rigidity, there are several reasons why the upper tail of the wage change distribution may be compressed in the presence of downward wage rigidity. Firstly, firms may attenuate wage increases actively, as they know that high wage growth today increases the likelihood that wage rigidity binds in the future. Secondly, when workers who want to swap employers because the value of their outside option exceeds their current wage are confronted with moving frictions, they may accept a delay before bidding up their wage to the outside option. Finally, as downward wage rigidity has swept up wages in the past, the increase that is necessary to reach the desired wage level is reduced. Attenuated wage growth in the presumably flexible upper part of the wage change distribution may thus explain the low estimate of notional wage growth and the corresponding high estimate of the wage sweep-up.

As for the propensity to be in a real rigid regime, an estimate of $47 \%$ seems low compared to the available data on the fraction of the work force covered by collective bargaining agreements. It also seems low when compared to an average propensity to be in a real rigid regime of above $70 \%$, reported by Pfeiffer (2003a, p.204). The latter value corresponds to firm stayers only, whereas in our sample there are stayers and movers. However, our results are the same if we exclude movers, as they represent only a small fraction of the sample. The lower estimate of the propensity of the real rigid regime in our analysis may be due to a different treatment of overtime hours worked. When computing hourly wages we take into account overtime hours worked in 
order to have a more appropriate measure of effective hourly labour costs. By varying paid and unpaid overtime, the hourly wage becomes more flexible (see footnote 3, p. 12). Growth rates of labour costs adjusted for overtime use may in a number of cases be below the collectively bargained wage growth rate, leading to a low measured value of the propensity of the real rigid regime. In fact, when we run the wage rigidity model on a sample of workers that did not have variations in the number of overtime hours worked, the propensity of the real rigid regime increases from $47 \%$ to $62 \%$ (see panel (b) of Table 5). This suggests that overtime use provides some flexibility of effective labour costs. If flexibility is gained through unpaid overtime, it cannot be captured in the IABS data set, because information on hours worked is missing. If this kind of flexibility is important, the studies of wage rigidity relying on this data source (Fehr, Goette and Pfeiffer 2002 / Pfeiffer 2003a / Bauer, Bonin and Sunde 2003) tend to overestimate the degree of wage rigidity.

Before turning to the effects of wage rigidity on mobility, we explore the heterogeneity of the wage sweep-up. There is considerable variation at individual level, with the wage sweep-up varying from 0 to $17 \%$. The $95^{\text {th }}$ percentile of the distribution of the wage sweep-up is at $5.2 \%$ (see Table 6 for percentiles of the distribution). We break down the estimated wage sweep-up by several individual and firm characteristics (Table 7) and we regress the wage sweep-up on these characteristics (Table 8).

Table 7 reveals that women have a higher wage sweep-up than men. This finding matches the results of Pfeiffer (2003b), who also finds a higher wage sweep-up for women. Foreign workers have a lower wage sweep-up than German workers. There is no clear relationship between the wage sweep-up and firm size. Job stayers have a wage sweep-up close to average. The wage sweep-up is low for external job movers, which suggests that wage setting for newly recruited workers is more flexible. For workers laid off at their previous employer and for workers separating after a firm closure, it seems to be entirely flexible; the sweep-up is nearly zero. Workers promoted in the preceding period have a wage sweep-up above average. Workers who were transferred internally display a below average wage sweep-up. These two last results suggest that there is some scope for employers to reduce wage sweep-up by either reducing promotions or by transferring workers to different positions. The wage sweep-up is higher in the public sector than in the private sector. It rises with tenure and experience. The relationship with schooling is not very clear. The status in the hierarchy does not seem to influence the wage sweep-up much.

The results of a regression of the wage sweep-up on explanatory variables are reported in Table 8. The regression largely replicates the bivariate cross-tabulations. In addition to the results already mentioned, the regression reveals that lower wages seem to be associated with a higher wage sweep-up. This effect is consistent with over proportionate wage increases for low wage 
earners, a strategy that trade unions have pursued in Germany. However, the coefficient of the wage level appears numerically rather small. It implies that dropping from the $90^{\text {th }}$ percentile $(\sim 25 €)$ to the $10^{\text {th }}$ percentile $(\sim 3.5 €)$ of the distribution of hourly wages increases the wage sweep-up by 0.4 percentage points ${ }^{13}$. The standardised beta coefficient of the wage level (Table 8 ) is also relatively small. Larger parts of the variation in the wage sweep-up are explained by tenure, experience, sex, private or public sector, schooling and external mobility variables.

Figure 1 compares the observed wage change distribution of 1996 from our data set with the wage change distribution simulated (i) with the rigidity model parameterised at our estimated parameter values and (ii) by a simple OLS estimation of wage growth. Even though our wage rigidity model estimates do not manage to fully account for the peak at zero nominal wage change (due to the low propensity of the nominal rigid regime), it accounts for the characteristic clustering of wage change observations around the real rigidity threshold and for a certain thinning of the density in the lower parts of the distribution.

\subsection{The effect of wage rigidity on mobility}

Table 9 breaks down the wage sweep-up by workers' reported subjective probabilities of job mobility events. Workers who report that own job search activities are unlikely have a wage sweep-up above average, while those who report job search activities as certain have a wage sweep-up below average. Wage sweep-up seems to reduce job search activities and it should consequently reduce quit behaviour.

On average, workers who evaluate a future job loss as unlikely have a higher wage sweep-up, workers who evaluate a future job loss as certain or probable display a lower wage sweep-up. Higher wage sweep-up does not seem to be associated with a higher subjectively anticipated job insecurity. Consequently, it can be expected that wage sweep-up does not increase the probability of layoffs.

As for promotions, workers who evaluate a future promotion as certain or probable display an average wage sweep-up below the mean, whereas workers who report a promotion as unlikely display a wage sweep-up above the mean. Judging from workers' subjective evaluation, wage sweep-up seems to lower the chances of promotion.

In the following analysis, heteroscedastic probit regressions of quits, layoffs, promotions and transfers are presented, where the wage sweep-up is included as a regressor. For all mobility regressions, a likelihood-ratio test rejects a restricted homoscedastic model in favour of the heteroscedastic model. In the heteroscedastic probit model stated above ( see equation (20) ), explanatory variables can be in the $\boldsymbol{x}$-vector that determines the mean and in the $\boldsymbol{z}$-vector that determines the standard deviation of the latent variable underlying the probit model. We have

${ }^{13}(3.5-21)^{*}(-0.0002)^{*} 100$ 
specified the equation of the standard deviation of the latent variable (z-vector) by first including all variables from the mean equation (i.e. of the $\boldsymbol{x}$-vector) and then retaining only those that were statistically significant. Variables that remain in both equations influence the probability of the outcome through a mean effect and a variance effect. The marginal effect of a variable that is in both $\boldsymbol{x}$ and $\boldsymbol{z}$ cannot be readily seen from the sign of the respective $\beta$ and $\gamma$-coefficients. As stated above ( see equation (21) ), it can be calculated for each individual as a combination of $\beta_{k}$ and $\gamma_{k}$ as well as of the linear combinations $x^{\prime} \beta$ and $z^{\prime} \gamma$. The marginal effect can vary in sign for different individuals. For the layoff and promotion regression, where the wage sweep-up enters the mean and the variance equation, we therefore not only report marginal effects of the wage sweep-up calculated at means, but we also report the distribution of the individual marginal effects in the sample.

The results of the probit regressions are largely in line with the first impressions given by the cross-tabulation of the reported subjective probability of future mobility events and the wage sweep-up ${ }^{14}$.

Quits

Table 10 reports probit regressions of quit decisions on the wage level, the wage sweep-up and other control variables.

The wage sweep-up coefficient has the expected negative sign, but it is insignificant in the general estimation sample. Table 11 reports the coefficient of the wage sweep-up on quits for estimation in different sub-samples. In separate regressions for men, full-time workers (weekly hours $>=35$ ) and employees of large firms, the coefficient of the wage sweep-up is negative and significant. A high wage sweep-up seems to reduce the propensity to quit. For these labour market groups, our hypothesis 3 is confirmed. This is in line with the results of Altonji and Devereux (2000) who find modest support for the hypothesis that a higher wage sweep-up reduces the propensity to quit.

Wage sweep-up may influence women's quit behaviour less systematically than that of men, because women's quit behaviour depends more strongly on factors other than wage sweep-up. These include child bearing and raising, lower wage rates that make women more likely to be secondary earners that only enter the work force temporarily, and the fact that family migration is added to their own quitting behaviour (Viscusi 1980).

In the quit regression, the control variables are mostly significant. Foreigners are less likely to quit than German employees, possibly because their outside labour market opportunities are worse. More educated workers are more likely to quit, supposedly because they have better labour market opportunities. The propensity to quit declines with tenure, as more firm specific

\footnotetext{
${ }^{14}$ We use a linear specification with respect to tenure in all mobility regressions. Experimentation with an additional quadratic term of tenure indicated that, though statistically significant, the quadratic component was numerically negligible and did not influence the relationships for any relevant range of tenure.
} 
capital is acquired. Employees of large firms are less likely to quit, which concurs with the idea that production in large companies is more human capital intensive and consequently matches tend to last longer. Furthermore, large firms may provide more internal career opportunities than small firms. Workers who have had a larger number of external job moves in the past are more likely to quit, reflecting preferences for mobility or low mobility costs. Finally, public sector workers are less likely to quit, possibly reflecting a self selection of less mobile individuals or individuals with high moving costs into the public sector with its higher job security.

\section{Layoffs}

Table 12 reports probit regressions of layoff decisions on the wage level, the wage sweep-up and other control variables. The marginal effect at means of the wage sweep-up on the propensity of a layoff is negative and it is based on highly significant coefficients of the wage sweep-up in the mean effect and in the variance effect equations. These findings confirm hypothesis 4b. Individuals with a high wage sweep-up are less likely to be laid off. The marginal effect at means is $-0.4 \%$. This suggests that for an average individual an increase in the wage sweep-up of one percentage point, say from $3 \%$ to $4 \%$, reduces the propensity of being laid off by 0.4 percentage points. This is a quite sizeable effect if compared to the sample probability of a layoff of $1.94 \%$. Table 13 reports the distribution of the individual marginal effects of the wage sweep-up on layoffs in the sample. The marginal effect is negative not only for an average individual, but it is still negative at the $95^{\text {th }}$ percentile. Only $0.9 \%$ of the individuals in the sample have a positive predicted marginal effect of the wage sweep-up on layoffs. Estimations in different sub-samples not reported here confirm the general pattern that wage sweep-up leads to a decreased risk of layoffs for different labour market sub-groups.

A negative relationship between wage sweep-up and layoffs is consistent with a core-periphery view of the labour force, where a core work force is at the same time protected from layoffs and from wage cuts, whereas a peripheral work force suffers from both, flexible wages and more insecure jobs. This may be because employers view wage sweep-up as an instrument of enhancing motivation and productivity, reducing turnover and providing incentives to invest into match-specific capital. They target this instrument towards those workers they want to tie to the firm and they try to avoid laying these workers off. Alternatively, high wage sweep-up workers may be insiders endowed with bargaining power and particularly protected from layoffs by labour legislation. So far, the results are consistent with both wage rigidity due to efficiency reasons and wage rigidity due to bargaining power.

Our results match the findings of Pfeiffer (2003a, p. 255ff) that workers with a higher wage sweep-up do not face an increased risk of unemployment and that they have a reduced probability of changing the establishment within the following year. 
The coefficients of the control variables are in line with expectations. A higher wage level reduces the probability of layoffs. When controlled for the wage sweep-up we think of the wage level as an indicator of the productivity of the match. Better matches are less likely to be ended by layoffs. Individuals with a higher number of skill trainings in the past are less likely to be laid off. The likelihood of layoffs also decreases with tenure, as more match-specific human capital is accumulated. Larger firms lay workers off less frequently, which may be due to the fact that they can diversify the risks of negative product market shocks better and therefore are not as quickly obliged to resort to layoffs. Workers that have changed employers more frequently in the past are more likely to be laid off. Layoffs for workers in the public sector are significantly less frequent. A number of year and industry dummies are significant.

\section{Promotions}

Table 14 reports probit regressions of promotions on the wage level, the wage sweep-up and other control variables. The marginal effect at means of the wage sweep-up on the propensity of being promoted is negative. The coefficients of the wage sweep-up in the mean effect and in the variance effect equations are significant at the $5 \%$ level. These findings confirm our hypothesis 5b. Individuals with a high wage sweep-up are less likely to be promoted. The marginal effect at means is $-0.1 \%$. This suggests that for an average individual an increase of the wage sweep-up of one percentage point, say from $3 \%$ to $4 \%$, reduces the propensity of being promoted by 0.1 percentage points. For comparison, the sample probability of receiving a promotion is $1.28 \%$. Table 15 reports the distribution of the individual marginal effects of the wage sweep-up on promotions in the sample. The marginal effect is negative not only for an average individual, but it is still negative at the $95^{\text {th }}$ percentile. Only $3.8 \%$ of the individuals in the sample have a positive predicted marginal effect of the wage sweep-up on promotions. Descriptive statistics not reported here reveal that almost all individuals who received a skill training in the preceding period are in this group. Conditional on having received a skill-training in the preceding period, the marginal effect of promotions in the estimation sample is positive, while for more than $95 \%$ of the estimation sample the effect is negative. Estimations in different sub-samples not reported here also confirm the general pattern that wage sweep-up leads to a decreased risk of promotions for the majority of individuals in different labour market sub-groups.

Those individuals with a high wage sweep-up are less likely to be promoted. Not promoting a worker potentially depresses morale and productivity and it would not seem a suitable response to wage sweep-up that exists as an incentive and motivation device. Instead, it seems to be a strategy to mitigate the effects of wage rigidity imposed upon the employer through bargaining power.

The other control variables in the promotion regression are mostly significant. The likelihood of promotions decreases with a higher wage level, possibly reflecting the fact that workers with a higher wage level are already in higher positions. The same argument may hold for the negative 
effect of tenure. Promotion is less likely for foreigners and for workers who have changed employers more frequently in the past, whereas it is more likely for higher educated workers, workers that had vocational training in the preceding year, public sector workers and workers of a higher occupational status. It also increases with firm size, which may be due to the fact that promotions as a motivation device are more important in large firms where monitoring is more difficult and shirking more costly due to a higher capital intensity of production.

\section{Transfers}

Table 16 reports probit regressions of transfers on the wage level, the wage sweep-up and other control variables. The wage sweep-up coefficient has a negative sign and is insignificant. Public sector workers and workers with higher schooling are more likely to be transferred. Workers who had a skill training in the preceding year and workers with higher tenure are less likely to be transferred.

Table 17 reports the coefficient of the wage sweep-up on transfers for estimation in different sub-samples. The effect of the wage sweep-up on transfers is negative and significant in an estimation for public sector workers only. None of our estimations shows a positive significant effect. We find almost no systematic relationship between wage sweep-up and internal transfers and we cannot confirm hypothesis 6 .

\section{Numerical effect of the wage sweep-up on job mobility}

Table 18 reports predicted probabilities of job mobility events for three hypothetical worker types in 2002. The predictions are reported at alternative values for the wage sweep-up: $2.5 \%$ and $4 \%$, which represent the $25^{\text {th }}$ and $75^{\text {th }}$ percentile of the wage sweep-up distribution. We omit internal transfers, as predictions would be based on a model with no significant coefficients. Individual A, termed "average individual", is a male German intermediate status employee with an hourly wage level of 13 euros in the manufacturing industry. He works in a firm of more than 2000 employees, where he has a tenure of 12 years. He had one skill training in the past dating back longer than one year and he changed his employer once. At a wage sweep-up of $2.5 \%$, individual $A$ would have a predicted probability to quit of $0.65 \%$, a predicted probability to be laid off of $1.02 \%$ and a predicted probability of being promoted of $1.78 \%$. If instead of $2.5 \%$ he had a wage sweep-up of $4 \%$, his probability to be laid off would decline to $0.49 \%$, either because the wage sweep-up signals that his employer wants to motivate and keep him as a good worker, or because the wage sweep-up signals that labour legislation protects him from layoffs and, at the same time, provides him with bargaining power. His probability to be promoted would drop to $1.38 \%$, suggesting that he had to "pay" for the wage sweep-up through a decrease in future promotion opportunities. At the higher wage sweep-up the predicted probability to quit drops to $0.57 \%$ which suggests that the net advantage of the wage sweep-up is still positive. Firms do not seem to compensate for downward wage rigidity to the full extent through decreased 
promotion opportunities. This may be because they accept the part of wage rigidity that exists for efficiency reasons and they only try to circumvent that part of wage rigidity that is due to bargaining power.

Table 18 also reports predicted mobility probabilities for a worker type B with "loose labour market ties" and C with "strong labour market ties" (see Table 18 for exact characteristics of the individuals).

Individual B, "tied loosely to the labour market", has noticeably higher probabilities of external mobility and a lower probability of being promoted than the average individual A. Individual C, "tied strongly to the labour market", has lower probabilities of external mobility and a higher probability of being promoted than the average individual $A$. For both types, $B$ and $C$, the decline in mobility probabilities as the wage sweep-up rises is qualitatively similar to individual $A$.

\section{Conclusion}

Using data from the German Socio-Economic Panel (GSOEP), we have analysed the extent of real and nominal downward wage rigidity as well as its effect on labour mobility in Germany over the period of $1985-2002$.

In the first step we measured the extent of wage rigidity. Under the assumption that downward nominal and real wage rigidity affect the lower part of the wage growth distribution and not the upper part, we have estimated notional wage growth, i.e. the wage growth that would prevail in absence of wage rigidity. If the assumption holds, actual wage growth equals notional wage growth in the upper part of the wage distribution. We have applied a quantile regression of the $75^{\text {th }}$ percentile to actual wage growth and taken this as a measure of the $75^{\text {th }}$ percentile of notional wage growth. Subsequently, using an empirical model that explicitly allows for downward nominal and real wage rigidity as well as for measurement error, we have estimated a set of parameters that are informative about the extent of wage rigidity. These include expected notional wage growth, the wage sweep-up and the fractions of the work force that have their wages set in a nominal rigid, real rigid or flexible regime. On average, over the whole period we find that notional wage growth is about $1.4 \%$ and that wages are swept up by $3.3 \%$, which leads to an expected actual wage growth of $4.7 \%$. We acknowledge that the wage sweep-up may be over-estimated if the assumption that only the lower parts of the earnings distribution are affected by wage rigidity does not hold. In fact, it may be that firms react to downward wage rigidity by moderating actual wage growth in the upper parts of the distribution.

According to our estimations, the wage sweep-up is virtually in its entirety due to real wage rigidity. For $47 \%$ of the work force, wages are set in a real rigid regime, for $0.6 \%$ in a nominally rigid regime, and for $52.4 \%$ in a flexible regime. These results are based on effective wage costs adjusted for paid and unpaid overtime hours. When only sampling individuals that have 
had no change in overtime hours worked, i.e. when ignoring the flexibility provided by overtime use, we have estimated that $62 \%$ of the work force are in a real rigid regime. As the wage sweep-up and the regime propensities are estimated at individual level, there is heterogeneity of the propensity to be in a rigid regime and of the wage sweep-up. Females, higher educated workers, workers with higher tenure and public sector workers are more likely to be in a real rigid regime. Wages are virtually flexible for workers who change employers. The heterogeneity of the wage sweep-up corresponds closely to the heterogeneity of the real rigid regime.

In the second step, we estimated probit equations to measure the effect of the wage sweep-up on layoffs, quits, promotions and internal transfers of personnel. According to our results, the effect of the wage sweep-up on quits of male workers is negative. Wage sweep-up seems to constitute a job specific net advantage. Layoffs are negatively related to wage sweep-up. This is consistent with a dual labour force concept, where a core work force is at the same time protected from layoffs and from wage cuts, whereas a peripheral work force suffers from both, flexible wages and more insecure jobs and provides a buffer for adjustment. However, on the basis of the results for external job mobility we cannot discriminate between two concurring explanations: (i) employers aiming at motivating the core work force and tying it to the firm by preventing it from wage cuts and layoffs, or (ii) the core work force being endowed with bargaining power to avoid wage cuts and simultaneously being protected from layoffs by labour legislation or norms.

As for internal job mobility, we have found almost no systematic relationship between wage sweep-up and internal transfers. However, we have found evidence that promotions are negatively related to wage sweep-up. This gives some weight to the explanation of wage rigidity through bargaining power. Not promoting a worker in itself depresses morale and productivity and it would not seem a suitable response to wage sweep-up that exists for reasons of motivation. Instead, it seems to be a strategy to mitigate the effects of wage rigidity imposed upon the employer through bargaining power.

The fact that workers quit less when in jobs with downwardly rigid wages suggests that the cost of decreased promotion opportunities does not fully outweigh the benefit of generous wage growth and of a decreased risk of layoffs. From this finding we conclude that only a part of wage rigidity (that part due to bargaining power) has to be "paid for" by lower promotion opportunities, while another part (that part due to efficiency reasons) constitutes a net advantage of the current job. 


\section{References}

Abowd, J.M., P. Corbel and F. Kramarz (1998): The Entry and Exit of Workers and the Growth of Employment: An Analysis of French Establishments, Review of Economics and Statistics, 81 (2), May, 170-187.

Akerlof, G.A. (1982): Labor Contracts as Partial Gift Exchange, Quarterly Journal of Economics, 97, 543569.

Akerlof, G. A. and Janet L. Yellen (1988): Fairness and Unemployment, American Economic Review, Papers and Proceedings, 78, 44-49.

Altonji, J. G. and P. J. Devereux (2000): The Extent and Consequences of Downward Nominal Wage Rigidity, Research in Labor Economics, Vol. 19, 383-431.

Barwell, R. D. and M. E. Schweitzer (2004): The Incidence of Nominal and Real Wage Rigidities in Great Britain: 1987 - 1998, paper presented at the EALE conference 2004.

Bauer, T., H. Bonin and U. Sunde (2003): Real and Nominal Wage Rigidities and the Rate of Inflation: Evidence from German Micro Data, IZA Discussion Paper 959.

Beissinger, T. and C. Knoppik (2001): Downward Nominal Rigidity in West-German Earnings 1975-1995, German Economic Review, 2(4), 385-417.

Bewley, T. (1999): Why Wages Don't Fall During A Recession, Harvard University Press, Cambridge.

Buchinsky, M. (1998): Recent Advances in Quantile Regression Models: A Practical Guideline for Empirical Research, Journal of Human Resources, 33(1), 88-126.

Card, D. and D. Hyslop (1997): Does Inflation "Grease the Wheels of the Labor Market"?, In: Romer, Christina D. and Romer, David H. (Eds.), Reducing Inflation - Motivation and Strategy, Chicago, London, University of Chicago Press, 71-114.

Cramer, U. and M. Koller (1988): Gewinne und Verluste von Arbeitsplätzen - der "Job-Turnover"-Ansatz, Mitteilungen aus der Arbeitsmarkt- und Berufsforschung, 3, 21. Jg, 361-380.

Devicienti, F. (2003): Downward Nominal Wage Rigidity in Italy: Evidence and Consequences, LABORatorio Riccardo Revelli Working Paper No. 20.

Devicienti, F., A. Maida and P. Sestito (2003): Nominal and Real wage Rigidity: An Assessment Using Italian Microdata, mimeo.

Dickens, W and L. Goette (2002): Notes on Estimating Rigidity using an Analytic Likelihood Function, mimeo.

Doeringer P. and M.J. Piore (1971): Internal Labor Markets and Manpower Analysis, Lexington, MA: D.C. Heath.

Erlinghagen, M. and M. Knuth (2004): In search of turbulence - Labour market mobility and job stability in Germany, European Societies, 6 (1), 49-70.

Elsby, M. W. L. (2004): Evaluating the Economic Significance of Downward Nominal Wage Rigidity, mimeo.

Fehr, E. and A. Falk (1999): Wage Rigidity in a Competitive Incomplete Contract Market, Journal of Political Economics, 107 (1), 106-134. 
Fehr, E. und S. Gächter (2000): Fairness and Retaliation: The Economics of Reciprocity, Journal of Economic Perspectives, 14 (3), 159-181.

Fehr, E. and L. Goette (2002): Robustness and Real Consequences of Nominal Wage Rigidities, Working Paper No. 44, Institute for Empirical Research in Economics, University of Zurich.

Fehr, E., Goette, L. and F. Pfeiffer (2002): Dimensions and Consequences of Wage Rigidities in Germany, ZEW and University of Zurich, mimeo.

Franz, W. and F. Pfeiffer (2003): Zur ökonomischen Rationalität von Lohnrigiditäten aus Sicht von Unternehmen, Jahrbücher $f$. Nationalökonomie u. Statistik, Bd. 223/1, 23-57.

Gerlach, K. and O. Hübler (1992): Zuschläge zum Lohnpotential und individuelle Arbeitslosigkeit, in: W. Franz (ed.), Mikro- und makroökonomische Aspekte der Arbeitslosigkeit, BeitrAB 165, 146-174.

Gerlach, K. and G. Stephan (2004): Betriebszugehörigkeit, Betriebseffekte und industrielle Beziehungen. In: O. Struck \& C. Köhler (Hrsg.), Beschäftigungsstabilität im Wandel?: empirische Befunde und theoretische Erklärungen für West- und Ostdeutschland, München u.a.: Hampp, 157-180.

Greene, W. (2003): Econometric Analysis, Prentice Hall, New Jersey.

Haisken-DeNew, J.P. and J.R. Frick (Ed.) (2003): Desktop Companion to the German Socio-Economic Panel study, Version 7.0, DIW Berlin.

Hall, R. E. (2003): Wage Determination and Employment Fluctuations, NBER Working Paper No. w9967.

Hall, R.E. (2004): Employment Efficiency and Sticky Wages: Evidence from Flows in the Labor Market, Review of Economics and Statistics Lecture, August 2004.

Hart, R. A. (2003): Worker-Job Matches, Job Mobility, and Real Wage Cyclicality, IZA Discussion Paper 881.

Holden, S. (2002): Downward nominal wage rigidity - contracts or fairness considerations?, mimeo 2002.

Johnson, W.R. (1978): A Theory of Job-Shopping, Quarterly Journal of Economics, 92, 261-277.

Kahn, S. (1997): Evidence of Nominal Wage Stickiness from Microdata, American Economic Review, 87(5), 993-1008.

Keynes, J.M. (1936): The General Theory of Employment, Interest and Money, Macmillan Cambridge University Press.

Knoppik, C. and T. Beissinger (2003): How Rigid are Nominal Wages? Evidence and Implications for Germany, Scandinavian Journal of Economics, 105(4), 643-659.

Koenker, R. and K. F. Hallock (2001): Quantile Regression, Journal of Economic Perspectives, 15 (4), 143-156.

Kohaut, S. and C. Schnabel (2003a): Verbreitung, Ausmaß und Determinanten der übertariflichen Entlohnung, Mitteilungen aus der Arbeitsmarkt- und Berufsforschung, 36 (4), 661-671

Kohaut, S. und C. Schnabel (2003b): Tarifverträge - nein danke!? Ausmaß und Einflussfaktoren der Tarifbindung west- und ostdeutscher Betriebe, Jahrbücher für Nationalökonomie und Statistik 223, 312331.

F. Kramarz (2001): Rigid Wages: What Have we Learnt from Microeconometric Studies, in: J. Drèze (ed.): Advances in Macroeconomic Theory, Oxford University Press, Oxford, UK, 194-216. 
Lazear, E.P. (1998): Personnel Economics for Mangers, New York, Wiley and Sons.

Lazear, E.P. (1999): Personnel Economics: Past Lessons and Future Directions, Journal of Labor Economics. 17, 199-236.

Lazear, E.P. and S. Rosen (1981): Rank-Order Tournaments as Optiumum Labor Contracts, Journal of Political Economy 89, 841-864.

Lindbeck A. and D.J. Snower (2001): Insiders versus Outsiders, Journal of Economic Perspectives 15, $165-188$.

MacLeod, W. B. and J. M. Malcomson (1993): Investments, Holdup, and the Form of Market Contracts, American Economic Review 83, 811-837.

Malcomson, J.M. (1997): Contracts, Hold-Up, and Labor Markets, Journal of Economic Literature 35, 1916-1957.

McLaughlin, K.J. (1994): Rigid Wages?, Journal of Monetary Economics 34, 383-414.

Mortensen, D.T. (1986): Job Search an Labor Market Analysis, in: Ashenfelter, O. and R. Layard (Eds.), Handbook of Labor Economics Vol. II, North-Holland, Amsterdam, 849-919.

Moulton, B.R. (1990): An Illustration of a Pitfall in Estimating the Effects of Aggregate Variables on Microdata, The Review of Economics and Statistics. 72, 334-338.

Pfeiffer, F. (2003a): Lohnrigiditäten im gemischten Lohnbildungssystem, ZEW Wirtschaftsanalysen Band 65, Baden-Baden, Nomos.

Pfeiffer, F. (2003b): Ausmaß und Konsequenzen von Lohnrigiditäten, Mitteilungen aus der Arbeitsmarktund Berufsforschung, 4/2003, 616-633.

Saint-Paul, G. (1996): Dual Labor Markets: A Macroeconomic Perspective, MIT Press, Cambridge.

Shapiro, C. and Stiglitz, J. (1984): Equilibrium Unemployment as Worker Discipline Device, American Economic Review 74, 433-444.

Smith, J. C. (2000): Nominal Wage Rigidity in the United Kingdom, Economic Journal, 110, C176-C195.

Solon, G., Whatley, W. and A. H. Stevens, (1997): Wage Changes and Intrafirm Job Mobility over the Business Cycle: Two case studies, Industrial and Labor Relations Review 50, 402-415.

Tobin, J. (1972): Inflation and Unemployment, American Economic Review 62, 1-18.

Viscusi, W.K. (1980): Sex Differences in Worker Quitting, Review of Economics and Statistics 62, 388398. 
Appendix A: Variables and descriptive statistics

\begin{tabular}{|c|c|c|c|c|c|c|c|}
\hline Variable & Description & $\begin{array}{l}\text { Source of } \\
\text { variable (GSOEP } \\
\text { codes 2001) }\end{array}$ & Mean & $\begin{array}{l}\text { Std. } \\
\text { Deviation }\end{array}$ & Min & Max & $\mathbf{N}$ \\
\hline age & Age & gebjahr & 40.507 & 10.592 & 18 & 64 & 36944 \\
\hline year 1985 & year dummy & welle & 0.039 & 0.193 & 0 & 1 & 36944 \\
\hline year 1986 & $-"$ - & welle & 0.039 & 0.194 & 0 & 1 & 36944 \\
\hline year 1987 & $-"$ - & welle & 0.038 & 0.191 & 0 & 1 & 36944 \\
\hline year 1988 & $-"$ - & welle & 0.038 & 0.190 & 0 & 1 & 36944 \\
\hline year 1989 & $-"$ - & welle & 0.041 & 0.198 & 0 & 1 & 36944 \\
\hline year 1990 & - " - & welle & 0.041 & 0.199 & 0 & 1 & 36944 \\
\hline year 1991 & - " - & welle & 0.043 & 0.202 & 0 & 1 & 36944 \\
\hline year 1992 & - " - & welle & 0.041 & 0.198 & 0 & 1 & 36944 \\
\hline year 1993 & - " - & welle & 0.041 & 0.198 & 0 & 1 & 36944 \\
\hline year 1994 & - " - & welle & 0.041 & 0.197 & 0 & 1 & 36944 \\
\hline year 1995 & - " - & welle & 0.085 & 0.278 & 0 & 1 & 36944 \\
\hline year 1996 & - " - & welle & 0.079 & 0.269 & 0 & 1 & 36944 \\
\hline year 1997 & - " - & welle & 0.069 & 0.254 & 0 & 1 & 36944 \\
\hline year 1998 & $-"$ - & welle & 0.075 & 0.263 & 0 & 1 & 36944 \\
\hline year 1999 & $-"$ - & welle & 0.078 & 0.268 & 0 & 1 & 36944 \\
\hline year 2000 & $-"$ - & welle & 0.090 & 0.287 & 0 & 1 & 36944 \\
\hline year 2001 & $-"$ - & welle & 0.080 & 0.272 & 0 & 1 & 36944 \\
\hline $\begin{array}{l}\text { internal stayer } \\
\text { in } \mathrm{t}-1\end{array}$ & $\begin{array}{l}\text { Worker did not change position } \\
\text { within firm in } \mathrm{t}-1\end{array}$ & rp25 & 0.980 & 0.139 & 0 & 1 & 36944 \\
\hline promotion t-1 & $\begin{array}{l}\text { Worker received promotion in t- } \\
1\end{array}$ & $\begin{array}{l}\text { rp25, rp2601 and } \\
\text { rp2602 }\end{array}$ & 0.013 & 0.115 & 0 & 1 & 36944 \\
\hline transfer $\mathrm{t}-1$ & $\begin{array}{l}\text { Worker was transferred } \\
\text { internally in } \mathrm{t}-1\end{array}$ & $\begin{array}{l}\text { rp25, rp2601 and } \\
\text { rp2602 }\end{array}$ & 0.006 & 0.080 & 0 & 1 & 36944 \\
\hline $\begin{array}{l}\text { external stayer } \\
\mathrm{t}-1\end{array}$ & $\begin{array}{l}\text { No external job change (change } \\
\text { of employer) }\end{array}$ & rp72 & 0.955 & 0.207 & 0 & 1 & 36944 \\
\hline quit t-1 & Quit in $\mathrm{t}-1$ & rp72 & 0.026 & 0.160 & 0 & 1 & 36944 \\
\hline layoff $t-1$ & Layoff in $\mathrm{t}-1$ & rp72 & 0.008 & 0.089 & 0 & 1 & 36944 \\
\hline firm closure t-1 & $\begin{array}{l}\text { Separation due to firm closure } \\
\text { in } \mathrm{t}-1\end{array}$ & rp72 & 0.003 & 0.053 & 0 & 1 & 36944 \\
\hline endcontract t-1 & $\begin{array}{l}\text { Separation due to end of } \\
\text { temporary contract in } \mathrm{t}-1\end{array}$ & rp72 & 0.003 & 0.056 & 0 & 1 & 36944 \\
\hline othermove t-1 & Other separation in $\mathrm{t}-1$ & rp72 & 0.005 & 0.067 & 0 & 1 & 36944 \\
\hline $\begin{array}{l}\text { Wage rounded } \\
\text { to } 100\end{array}$ & $\begin{array}{l}\text { Wage rounded to } 100 \text { in at least } \\
\text { one of two consecutive years. }\end{array}$ & - & 0.701 & 0.458 & 0 & 1 & 36944 \\
\hline
\end{tabular}


Std. Deviation Min Max N

\begin{tabular}{|c|c|c|c|c|c|c|c|}
\hline $\begin{array}{l}\text { Wage rounded } \\
\text { to } 1000\end{array}$ & $\begin{array}{l}\text { Wage rounded to } 1000 \text { in at } \\
\text { least one of two consecutive } \\
\text { years. }\end{array}$ & - & 0.113 & 0.316 & 0 & 1 & 36944 \\
\hline $\begin{array}{l}\text { Diff. Unempl. } \\
\text { Rate, t }\end{array}$ & $\begin{array}{l}\text { Difference in unemployment } \\
\text { rate between } \mathrm{t} \text { and } \mathrm{t}-1\end{array}$ & - & & & & & 36944 \\
\hline $\begin{array}{l}\text { Diff. Unempl. } \\
\text { Rate, t-1 }\end{array}$ & $\begin{array}{l}\text { Difference in unemployment } \\
\text { rate between } \mathrm{t}-1 \text { and } \mathrm{t}-2\end{array}$ & $\begin{array}{l}\text { Federal German } \\
\text { Labour Office }\end{array}$ & -0.021 & 0.831 & -1.2 & 2.8 & 36944 \\
\hline $\begin{array}{l}\text { Diff. Unempl. } \\
\text { Rate, t-2 }\end{array}$ & $\begin{array}{l}\text { Difference in unemployment } \\
\text { rate between } \mathrm{t}-2 \text { and } \mathrm{t}-3\end{array}$ & $\begin{array}{l}\text { Federal German } \\
\text { Labour Office }\end{array}$ & 0.094 & 0.888 & -1.2 & 2.8 & 36944 \\
\hline $\begin{array}{l}\text { education } \\
\text { parents }\end{array}$ & $\begin{array}{l}\text { parents educational level, } \\
\text { coded from } 0 \text { to } 5 \text { with } \\
\text { increasing level }\end{array}$ & $\begin{array}{l}\text { vsbil, msbil (file } \\
\text { bioparen) }\end{array}$ & 1.375 & 1.151 & 0 & 5 & 36944 \\
\hline experience $<=2$ & $\begin{array}{l}\text { potential experience } \\
\text { (age-schooling-6) }\end{array}$ & - & 0.002 & 0.040 & 0 & 1 & 36944 \\
\hline $\begin{array}{l}\text { experience }>2 \\
<=5\end{array}$ & $-"$ - & - & 0.024 & 0.153 & 0 & 1 & 36944 \\
\hline $\begin{array}{l}\text { experience }>5 \\
<=8\end{array}$ & $-"$ - & - & 0.062 & 0.242 & 0 & 1 & 36944 \\
\hline $\begin{array}{l}\text { experience }>8 \\
<=10\end{array}$ & $-"$ & - & 0.052 & 0.221 & 0 & 1 & 36944 \\
\hline $\begin{array}{l}\text { experience } \\
>10<=15\end{array}$ & - " - & - & 0.147 & 0.355 & 0 & 1 & 36944 \\
\hline $\begin{array}{l}\text { experience } \\
>15<=25\end{array}$ & - " - & - & 0.289 & 0.453 & 0 & 1 & 36944 \\
\hline $\begin{array}{l}\text { experience } \\
>25<=35\end{array}$ & $-"$ - & - & 0.256 & 0.436 & 0 & 1 & 36944 \\
\hline $\begin{array}{l}\text { experience } \\
>35<=45\end{array}$ & - " - & - & 0.159 & 0.366 & 0 & 1 & 36944 \\
\hline $\begin{array}{l}\text { experience } \\
>45\end{array}$ & $-"$ - & - & 0.009 & 0.093 & 0 & 1 & 36944 \\
\hline foreign & $\begin{array}{l}\text { Dummy for non-German } \\
\text { nationality }\end{array}$ & nation\$ & 0.183 & 0.386 & 0 & 1 & 36944 \\
\hline firm size $<20$ & Firm size & betr\$ & 0.157 & 0.364 & 0 & 1 & 36944 \\
\hline $\begin{array}{l}\text { firm size }>=20 \\
<200\end{array}$ & Firm size & betr\$ & 0.269 & 0.443 & 0 & 1 & 36944 \\
\hline $\begin{array}{l}\text { firm size }>= \\
200<2000\end{array}$ & Firm size & betr\$ & 0.258 & 0.437 & 0 & 1 & 36944 \\
\hline $\begin{array}{l}\text { firm size > } \\
2000\end{array}$ & Firm size & betr\$ & 0.317 & 0.465 & 0 & 1 & 36944 \\
\hline industry 10 & Dummy for industry & nace\$\$ & 0.000 & 0.017 & 0 & 1 & 36944 \\
\hline industry 11 & - " - & nace $\$ \$$ & 0.007 & 0.083 & 0 & 1 & 36944 \\
\hline industry 12 & - " - & nace $\$ \$$ & 0.006 & 0.079 & 0 & 1 & 36944 \\
\hline
\end{tabular}




\section{Variable \\ Description}

Source of

variable (GSOEP Mean

codes 2001)

\begin{tabular}{|c|c|c|c|c|c|c|c|}
\hline industry 13 & - " - & nace $\$ \$$ & 0.001 & 0.024 & 0 & 1 & 36944 \\
\hline industry 14 & $-"$ - & nace $\$ \$$ & 0.011 & 0.103 & 0 & 1 & 36944 \\
\hline industry 15 & - " - & nace $\$ \$$ & 0.010 & 0.097 & 0 & 1 & 36944 \\
\hline industry 16 & - " - & nace $\$ \$$ & 0.010 & 0.098 & 0 & 1 & 36944 \\
\hline industry 17 & - " - & nace $\$ \$$ & 0.001 & 0.038 & 0 & 1 & 36944 \\
\hline industry 18 & - " - & nace $\$ \$$ & 0.062 & 0.241 & 0 & 1 & 36944 \\
\hline industry 19 & - " - & nace $\$ \$$ & 0.009 & 0.094 & 0 & 1 & 36944 \\
\hline industry 20 & - " - & nace $\$ \$$ & 0.007 & 0.085 & 0 & 1 & 36944 \\
\hline industry 21 & $-"$ - & nace $\$ \$$ & 0.024 & 0.152 & 0 & 1 & 36944 \\
\hline industry 22 & - " - & nace $\$ \$$ & 0.050 & 0.219 & 0 & 1 & 36944 \\
\hline industry 23 & - " - & nace $\$ \$$ & 0.066 & 0.247 & 0 & 1 & 36944 \\
\hline industry 24 & $-"$ - & nace $\$ \$$ & 0.001 & 0.027 & 0 & 1 & 36944 \\
\hline industry 25 & - " - & nace $\$ \$$ & 0.045 & 0.207 & 0 & 1 & 36944 \\
\hline industry 26 & $-"$ - & nace $\$ \$$ & 0.005 & 0.070 & 0 & 1 & 36944 \\
\hline industry 27 & $-"$ - & nace $\$ \$$ & 0.018 & 0.131 & 0 & 1 & 36944 \\
\hline industry 28 & - " - & nace $\$ \$$ & 0.025 & 0.156 & 0 & 1 & 36944 \\
\hline industry 29 & $-"$ - & nace $\$ \$$ & 0.003 & 0.052 & 0 & 1 & 36944 \\
\hline industry 30 & - " - & nace $\$ \$$ & 0.005 & 0.072 & 0 & 1 & 36944 \\
\hline industry 31 & - " - & nace $\$ \$$ & 0.001 & 0.023 & 0 & 1 & 36944 \\
\hline industry 32 & - " - & nace $\$ \$$ & 0.017 & 0.129 & 0 & 1 & 36944 \\
\hline industry 33 & - " - & nace $\$ \$$ & 0.002 & 0.039 & 0 & 1 & 36944 \\
\hline industry 34 & - " - & nace $\$ \$$ & 0.124 & 0.329 & 0 & 1 & 36944 \\
\hline industry 35 & - " - & nace $\$ \$$ & 0.008 & 0.089 & 0 & 1 & 36944 \\
\hline industry 36 & - " - & nace\$\$ & 0.035 & 0.184 & 0 & 1 & 36944 \\
\hline industry 37 & $-"$ - & nace $\$ \$$ & 0.114 & 0.317 & 0 & 1 & 36944 \\
\hline industry 38 & - " - & nace $\$ \$$ & 0.007 & 0.083 & 0 & 1 & 36944 \\
\hline industry 39 & $-"$ - & nace $\$ \$$ & 0.034 & 0.181 & 0 & 1 & 36944 \\
\hline industry 4 & - " - & nace $\$ \$$ & 0.009 & 0.094 & 0 & 1 & 36944 \\
\hline industry 40 & - " - & nace $\$ \$$ & 0.000 & 0.021 & 0 & 1 & 36944 \\
\hline industry 41 & $-"$ - & nace $\$ \$$ & 0.001 & 0.032 & 0 & 1 & 36944 \\
\hline industry 42 & $-"$ - & nace $\$ \$$ & 0.008 & 0.091 & 0 & 1 & 36944 \\
\hline industry 43 & - " - & nace $\$ \$$ & 0.030 & 0.170 & 0 & 1 & 36944 \\
\hline industry 44 & $-"$ - & nace $\$ \$$ & 0.026 & 0.159 & 0 & 1 & 36944 \\
\hline
\end{tabular}




\begin{tabular}{|c|c|c|c|c|c|c|c|}
\hline Variable & Description & $\begin{array}{l}\text { Source of } \\
\text { variable (GSOEP } \\
\text { codes 2001) }\end{array}$ & Mean & $\begin{array}{l}\text { Std. } \\
\text { Deviation }\end{array}$ & Min & Max & $\mathbf{N}$ \\
\hline industry 45 & - " - & nace $\$ \$$ & 0.014 & 0.119 & 0 & 1 & 36944 \\
\hline industry 5 & $-"$ - & nace $\$ \$$ & 0.000 & 0.020 & 0 & 1 & 36944 \\
\hline industry 52 & - " - & nace $\$ \$$ & 0.167 & 0.373 & 0 & 1 & 36944 \\
\hline industry 64 & $-"$ - & nace $\$ \$$ & 0.002 & 0.040 & 0 & 1 & 36944 \\
\hline industry 7 & $-"$ - & nace $\$ \$$ & 0.000 & 0.013 & 0 & 1 & 36944 \\
\hline industry 8 & $-"$ - & nace $\$ \$$ & 0.001 & 0.025 & 0 & 1 & 36944 \\
\hline industry 9 & $-"$ - & nace $\$ \$$ & 0.037 & 0.189 & 0 & 1 & 36944 \\
\hline mining & Dummy for sector & $\begin{array}{l}\text { aggregation of } \\
\text { industry dummies }\end{array}$ & 0.029 & 0.166 & 0 & 1 & 36944 \\
\hline manufacturing & $-"$ - & - " - & 0.295 & 0.456 & 0 & 1 & 36944 \\
\hline $\begin{array}{l}\text { ressource } \\
\text { processing }\end{array}$ & - " - & - " - & 0.103 & 0.304 & 0 & 1 & 36944 \\
\hline $\begin{array}{l}\text { transp. \& } \\
\text { communication }\end{array}$ & $-"$ - & - " - & 0.078 & 0.269 & 0 & 1 & 36944 \\
\hline building sector & $-"$ - & - " - & 0.124 & 0.329 & 0 & 1 & 36944 \\
\hline retail & - " - & - " - & 0.157 & 0.364 & 0 & 1 & 36944 \\
\hline services & $-"$ - & - " - & 0.007 & 0.083 & 0 & 1 & 36944 \\
\hline $\begin{array}{l}\text { credit and } \\
\text { insurance }\end{array}$ & $-"$ - & - " - & 0.040 & 0.197 & 0 & 1 & 36944 \\
\hline public utilities & $-"$ - & - " - & 0.167 & 0.373 & 0 & 1 & 36944 \\
\hline $\begin{array}{l}\text { nominal GDP } \\
\text { growth }\end{array}$ & Nominal GDP growth & $\begin{array}{l}\text { German Council } \\
\text { of Economic } \\
\text { Experts }\end{array}$ & 0.038 & 0.022 & 0.018 & 0.09 & 36944 \\
\hline inflation & Inflation rate t & $\begin{array}{l}\text { Federal Statistical } \\
\text { Office }\end{array}$ & 1.873 & 1.198 & -0.12 & 5.13 & 36944 \\
\hline inflation, t-1 & Inflation rate $\mathrm{t}-1$ & $\begin{array}{l}\text { Federal Statistical } \\
\text { Office }\end{array}$ & 1.917 & 1.195 & -0.12 & 5.13 & 36944 \\
\hline inflation, t-2 & Inflation rate $\mathrm{t}-2$ & $\begin{array}{l}\text { Federal Statistical } \\
\text { Office }\end{array}$ & 1.984 & 1.247 & -0.12 & 5.13 & 36944 \\
\hline male & Dummy for male gender & sex & 0.668 & 0.471 & 0 & 1 & 36944 \\
\hline $\begin{array}{l}\text { number } \\
\text { external moves }\end{array}$ & $\begin{array}{l}\text { Number of external job moves } \\
\text { in the past }\end{array}$ & $\begin{array}{l}\text { constructed from } \\
\text { job mobility } \\
\text { variables }\end{array}$ & 0.615 & 1.066 & 0 & 11 & 36944 \\
\hline overtime $=0$ & average weekly overtime hours & \$uebstd & 0.505 & 0.500 & 0 & 1 & 36944 \\
\hline $\begin{array}{l}\text { overtime }>0 \\
<=0.5\end{array}$ & average weekly overtime hours & \$uebstd & 0.015 & 0.120 & 0 & 1 & 36944 \\
\hline $\begin{array}{l}\text { overtime }>0.5 \\
<=1\end{array}$ & average weekly overtime hours & \$uebstd & 0.031 & 0.174 & 0 & 1 & 36944 \\
\hline
\end{tabular}




\begin{tabular}{|c|c|c|c|c|c|c|c|}
\hline Variable & Description & $\begin{array}{l}\text { Source of } \\
\text { variable (GSOEP } \\
\text { codes 2001) }\end{array}$ & Mean & $\begin{array}{l}\text { Std. } \\
\text { Deviation }\end{array}$ & Min & Max & $\mathbf{N}$ \\
\hline $\begin{array}{l}\text { overtime }>1 \\
<=2\end{array}$ & average weekly overtime hours & \$uebstd & 0.085 & 0.279 & 0 & 1 & 36944 \\
\hline $\begin{array}{l}\text { overtime }>2 \\
<=5\end{array}$ & average weekly overtime hours & \$uebstd & 0.230 & 0.421 & 0 & 1 & 36944 \\
\hline $\begin{array}{l}\text { overtime }>5 \\
<=10\end{array}$ & average weekly overtime hours & \$uebstd & 0.097 & 0.296 & 0 & 1 & 36944 \\
\hline $\begin{array}{l}\text { overtime }>10 \\
<=15\end{array}$ & average weekly overtime hours & \$uebstd & 0.023 & 0.151 & 0 & 1 & 36944 \\
\hline $\begin{array}{l}\text { overtime }>15 \\
<=20\end{array}$ & average weekly overtime hours & \$uebstd & 0.009 & 0.094 & 0 & 1 & 36944 \\
\hline $\begin{array}{l}\text { overtime }>20 \\
<=25\end{array}$ & average weekly overtime hours & \$uebstd & 0.005 & 0.067 & 0 & 1 & 36944 \\
\hline overtime $>25$ & average weekly overtime hours & \$uebstd & 0.000 & 0.016 & 0 & 1 & 36944 \\
\hline period $84-90$ & Dummy for period 1984-1990 & - & 0.236 & 0.425 & 0 & 1 & 36944 \\
\hline period $91-97$ & Dummy for period 1991-1997 & - & 0.371 & 0.483 & 0 & 1 & 36944 \\
\hline period $98-03$ & Dummy for period 1998-2003 & - & 0.393 & 0.488 & 0 & 1 & 36944 \\
\hline public sector & Dummy for public sector worker & oeffd $\$$ & 0.245 & 0.430 & 0 & 1 & 36944 \\
\hline East Germany & Dummy for East German states & \$bula & 0.128 & 0.334 & 0 & 1 & 36944 \\
\hline $\begin{array}{l}\text { South } \\
\text { Germany }\end{array}$ & $\begin{array}{l}\text { Dummy for South German } \\
\text { states }\end{array}$ & \$bula & 0.468 & 0.499 & 0 & 1 & 36944 \\
\hline schooling & years of schooling & \$bilzeit & 11.409 & 2.318 & 7 & 18 & 36944 \\
\hline $\begin{array}{l}\text { wage sweep- } \\
\text { up }\end{array}$ & $\begin{array}{l}\text { wage sweep-up estimated from } \\
\text { wage rigidity model }\end{array}$ & - & 0.033 & 0.012 & $\begin{array}{l}1.49 \\
\mathrm{E}-08\end{array}$ & 0.18 & 36944 \\
\hline tenure & tenure with current employer & \$erwzeit & 11.990 & 9.540 & 0 & 52 & 36944 \\
\hline tenure $<=1$ & Dummy for tenure & \$erwzeit & 0.046 & 0.209 & 0 & 1 & 36944 \\
\hline tenure $>1<=2$ & Dummy for tenure & \$erwzeit & 0.066 & 0.249 & 0 & 1 & 36944 \\
\hline tenure $>2<=3$ & Dummy for tenure & \$erwzeit & 0.063 & 0.243 & 0 & 1 & 36944 \\
\hline tenure $>3<=4$ & Dummy for tenure & \$erwzeit & 0.060 & 0.237 & 0 & 1 & 36944 \\
\hline tenure $>4<=5$ & Dummy for tenure & \$erwzeit & 0.058 & 0.233 & 0 & 1 & 36944 \\
\hline tenure $>5<=7$ & Dummy for tenure & \$erwzeit & 0.110 & 0.313 & 0 & 1 & 36944 \\
\hline $\begin{array}{l}\text { tenure }>7 \\
<=10\end{array}$ & Dummy for tenure & \$erwzeit & 0.128 & 0.334 & 0 & 1 & 36944 \\
\hline $\begin{array}{l}\text { tenure } \\
>10<=20\end{array}$ & Dummy for tenure & \$erwzeit & 0.260 & 0.439 & 0 & 1 & 36944 \\
\hline tenure $>20$ & Dummy for tenure & \$erwzeit & 0.209 & 0.407 & 0 & 1 & 36944 \\
\hline $\begin{array}{l}\text { months } \\
\text { unempl. last } \\
\text { year }\end{array}$ & $\begin{array}{l}\text { Number of months of } \\
\text { unemployment in preceding } \\
\text { year }\end{array}$ & rp1d02 (file \$pkal) & 0.038 & 0.414 & 0 & 12 & 36944 \\
\hline
\end{tabular}




\begin{tabular}{|c|c|c|c|c|c|c|c|}
\hline Variable & Description & $\begin{array}{l}\text { Source of } \\
\text { variable (GSOEP } \\
\text { codes 2001) }\end{array}$ & Mean & $\begin{array}{l}\text { Std. } \\
\text { Deviation }\end{array}$ & Min & Max & $\mathbf{N}$ \\
\hline $\begin{array}{l}\text { number skill } \\
\text { trainings }\end{array}$ & $\begin{array}{l}\text { Number of past skill trainings in } \\
\text { the survey period }\end{array}$ & - & 0.184 & 0.612 & 0 & 9 & 36944 \\
\hline $\begin{array}{l}\text { skill training } \\
\text { last period }\end{array}$ & $\begin{array}{l}\text { Dummy for skill training in the } \\
\text { preceding period }\end{array}$ & $\begin{array}{l}\text { rp1m01 (file } \\
\$ \text { \$pkal) }\end{array}$ & 0.019 & 0.138 & 0 & 1 & 36944 \\
\hline $\begin{array}{l}\text { hourly wage } \\
\text { level }\end{array}$ & $\begin{array}{l}\text { Hourly wage level (Monthly } \\
\text { wage divided by contractual + } \\
\text { overtime hours) }\end{array}$ & rp5701 & 12.852 & 5.209 & 1.63 & 82.9 & 36944 \\
\hline $\begin{array}{l}\text { low status } \\
\text { group }\end{array}$ & $\begin{array}{l}\text { low status blue-collar, white } \\
\text { collar or public service } \\
\text { employee }\end{array}$ & $\begin{array}{l}\text { rp4001, rp4005, } \\
\text { rp4004 }\end{array}$ & 0.276 & 0.447 & 0 & 1 & 36944 \\
\hline $\begin{array}{l}\text { intermediate } \\
\text { status group }\end{array}$ & $\begin{array}{l}\text { intermediate status blue-collar, } \\
\text { white collar or public service } \\
\text { employee }\end{array}$ & $\begin{array}{l}\text { rp4001, rp4005, } \\
\text { rp4005 }\end{array}$ & 0.592 & 0.492 & 0 & 1 & 36944 \\
\hline $\begin{array}{l}\text { high status } \\
\text { group }\end{array}$ & $\begin{array}{l}\text { high status blue-collar, white } \\
\text { collar or public service } \\
\text { employee }\end{array}$ & $\begin{array}{l}\text { rp4001, rp4005, } \\
\text { rp4006 }\end{array}$ & 0.132 & 0.339 & 0 & 1 & 36944 \\
\hline
\end{tabular}




\section{Appendix B: Job mobility variables in the GSOEP}

The GSOEP survey includes retrospective questions on job mobility. Respondents are asked whether there were any employment changes since the first of January of the preceding year and, if so, which types of changes ${ }^{15}$. If more than one job move has taken place since the start of the preceding year, only the last move is recorded. Job mobility is therefore potentially underestimated ${ }^{16}$. We use the response option "I have started a new position with a different employer" to identify external job mobility and „I have changed positions within the same company" to identify internal job mobility. External job moves can be further classified through another question that asks how the previous employment relationship was terminated 17 . We use the option „My resignation“ to identify quits and „Dismissal“ to identify layoffs. Internal job moves can be further classified through a question asking respondents to compare their current position with their previous one along several dimensions, including the type of work and the income $^{18}$. In our analysis, promotions qualify as those internal job moves where the worker either states an improved income or an unchanged income alongside improvements in the type of work. We regard the remaining internal moves as demotions or transfers.

With the given survey design, it is possible that job mobility events are counted twice. The survey asks about job mobility events that have occurred since the first of January of the preceding year up to the date of the interview. Surveys mainly take place during the first half of a year. Imagine a survey takes place in April 2000 and the respondent has moved jobs in February of that same year. The job move will be recorded in the survey of 2000. In the 2001 survey, the same person will be asked whether she has changed jobs since the $1^{\text {st }}$ of January 2000 . Hence, the respondent will declare the job move of February 2000 again in the 2001 survey if no other job move has recently taken place. As the month and year of the job moves are also recorded, we can identify and eliminate double counts.

If a move has taken place, wage data in the GSOEP usually corresponds to the wage in the new job, because wages of the month prior to the interview are recorded, whereas recorded job moves have taken place since the start of the preceding year. If a job move is declared to have taken place in the month of the survey interview, however, the wage of the last month would correspond to the wage of the old job. Therefore, we impute job moves that take place within the interview month to the next survey year and not to the preceding survey year.

Table 1 reports yearly external job mobility rates alongside nominal GDP growth in order to allow an assessment of the cyclicality of job mobility.

\footnotetext{
${ }^{15}$ e.g. questions 23 and 25 in the 2001 GSOEP questionnaire.

${ }^{16}$ An alternative would be to use the GSOEP calendar data. Respondents are asked to fill in a calendar with their monthly employment status during the preceding year. This data can identify multiple job moves within a given year if between two succeeding jobs there occurs a spell of unemployment or an other activity. However, the calendar data neither provides detail about the reasons of a job move nor about job changes at the same employer.

${ }^{17}$ e.g. questions 69 and 72 in the 2001 GSOEP questionnaire.

${ }^{18}$ e.g. question 26 in the 2001 GSOEP questionnaire.
} 
Table 1: External job mobility

\begin{tabular}{|c|c|c|c|c|c|c|c|}
\hline \multirow[b]{2}{*}{ Year } & \multirow{2}{*}{$\begin{array}{c}\text { Nominal } \\
\text { GDP } \\
\text { growth }\end{array}$} & \multicolumn{5}{|c|}{ External job mobility, percent } & \multirow[b]{2}{*}{$\mathrm{N}$} \\
\hline & & $\begin{array}{c}\text { Ext. } \\
\text { stayer }\end{array}$ & Quit & Layoff & Other $^{1)}$ & Total & \\
\hline 1985 & 4.4 & 94.3 & 2.0 & 2.0 & 1.7 & 100 & 1375 \\
\hline 1986 & 5.7 & 93.8 & 2.4 & 1.8 & 2.1 & 100 & 1359 \\
\hline 1987 & 3.3 & 93.8 & 2.3 & 1.1 & 2.9 & 100 & 1300 \\
\hline 1988 & 5.3 & 93.3 & 3.3 & 1.0 & 2.5 & 100 & 1260 \\
\hline 1989 & 6.4 & 93.3 & 4.0 & 0.9 & 1.9 & 100 & 1392 \\
\hline 1990 & 9.1 & 90.3 & 4.6 & 1.0 & 4.1 & 100 & 1465 \\
\hline 1991 & 8.8 & 89.0 & 4.7 & 1.0 & 5.3 & 100 & 1484 \\
\hline 1992 & 7.4 & 90.1 & 4.0 & 0.6 & 5.4 & 100 & 1437 \\
\hline 1993 & 2.5 & 89.5 & 2.6 & 2.9 & 5.0 & 100 & 1401 \\
\hline 1994 & 4.9 & 90.6 & 2.9 & 1.7 & 4.9 & 100 & 1392 \\
\hline 1995 & 3.8 & 90.4 & 3.7 & 1.9 & 4.0 & 100 & 1484 \\
\hline 1996 & 1.8 & 90.0 & 2.3 & 2.8 & 5.0 & 100 & 2906 \\
\hline 1997 & 2.1 & 91.0 & 2.2 & 2.6 & 4.2 & 100 & 2656 \\
\hline 1998 & 3.1 & 90.1 & 3.2 & 3.3 & 3.4 & 100 & 2382 \\
\hline 1999 & 2.6 & 90.3 & 3.5 & 2.0 & 4.2 & 100 & 2568 \\
\hline 2000 & 2.6 & 91.1 & 3.0 & 1.9 & 4.0 & 100 & 2640 \\
\hline 2001 & 2.2 & 91.7 & 2.8 & 2.0 & 3.5 & 100 & 3025 \\
\hline 2002 & 1.8 & 92.0 & 1.7 & 2.0 & 4.3 & 100 & 2774 \\
\hline Total & & 91.21 & 2.96 & 1.94 & 3.89 & 100 & 34300 \\
\hline
\end{tabular}

Mobility in year $t$ is constructed from retrospective survey question of year $t+1$. Sample: Observations included in the wage rigidity estimation sample, i.e. individuals for whom wage data and other regressors are available in $t$ and $\mathrm{t}-1$.

1) Other external moves include firm closure, end of temporary contract, maternity leave, retirement and others.

An annual separation rate of roughly $9 \%$ appears low when compared to labour turnover data from other studies. Using the IAB employment sub-sample Cramer and Koller (1988) estimate the annual labour turnover rate, defined as the mean of annual accessions and separations divided by total employment, at about $30-33 \%$ for West Germany between 1977 and 1987. Ehrlinghagen and Knuth (2002), using the same data set, measure labour turnover rates of $24-31 \%$ for West Germany between 1995 and 1997.

Firstly, job mobility is certainly underestimated in the GSOEP data because, as mentioned above, if more than one job move has taken place since the start of the preceding year, only the last move is recorded in the GSOEP survey. Secondly, our estimation sample for the wage rigidity model includes only observations, for which wage growth rates could be calculated, i.e. individuals that held a job and reported a wage in period $t$ as well as $\mathrm{t}-1$. More mobile persons are more likely to display a spell of unemployment or inactivity and therefore not to report a wage at a given point of time. This restriction further reduces job mobility $^{19}$. More generally, panel mortality may lead to an under estimation of job mobility, as geographically mobile individuals are more likely to drop out of the sample because it becomes more difficult to track them.

\footnotetext{
${ }^{19}$ If we lift this restriction, the separation rate rises to about $15 \%$.
} 
In Table 1 quits appear pro-cyclical while layoffs appear counter-cyclical. For example, quit rates are at their highest and layoff rates at their lowest level during the boom of the beginning of the 1990s.

Table 2 reports internal job mobility, again alongside nominal GDP growth for the assessment of the cyclicality of job mobility.

Table 2: Internal job mobility

\begin{tabular}{|c|c|c|c|c|c|c|}
\hline \multirow{2}{*}{ Year } & \multirow{2}{*}{$\begin{array}{c}\text { Nominal } \\
\text { GDP } \\
\text { growth }\end{array}$} & \multicolumn{4}{|c|}{ Internal job mobility, percent } & \multirow[b]{2}{*}{$\mathrm{N}$} \\
\hline & & $\begin{array}{c}\text { Internal } \\
\text { stayer }\end{array}$ & Promotion & Transfer & Total & \\
\hline 1985 & 4.4 & 96.7 & 2.3 & 1.0 & 100 & 1292 \\
\hline 1986 & 5.7 & 96.8 & 2.4 & 0.9 & 100 & 1274 \\
\hline 1987 & 3.3 & 97.5 & 1.6 & 0.9 & 100 & 1218 \\
\hline 1988 & 5.3 & 96.9 & 2.2 & 0.9 & 100 & 1173 \\
\hline 1989 & 6.4 & 97.2 & 1.9 & 0.9 & 100 & 1296 \\
\hline 1990 & 9.1 & 97.9 & 1.5 & 0.6 & 100 & 1321 \\
\hline 1991 & 8.8 & 97.6 & 1.8 & 0.6 & 100 & 1319 \\
\hline 1992 & 7.4 & 97.1 & 2.3 & 0.6 & 100 & 1292 \\
\hline 1993 & 2.5 & 99.1 & 0.6 & 0.2 & 100 & 1253 \\
\hline 1994 & 4.9 & 97.8 & 1.5 & 0.7 & 100 & 1259 \\
\hline 1995 & 3.8 & 98.7 & 0.8 & 0.5 & 100 & 1337 \\
\hline 1996 & 1.8 & 98.4 & 1.0 & 0.5 & 100 & 2606 \\
\hline 1997 & 2.1 & 98.7 & 1.0 & 0.4 & 100 & 2415 \\
\hline 1998 & 3.1 & 98.8 & 0.9 & 0.3 & 100 & 2145 \\
\hline 1999 & 2.6 & 98.4 & 0.9 & 0.7 & 100 & 2311 \\
\hline 2000 & 2.6 & 98.8 & 0.8 & 0.5 & 100 & 2392 \\
\hline 2001 & 2.2 & 98.8 & 0.7 & 0.5 & 100 & 2766 \\
\hline 2002 & 1.8 & 98.2 & 1.2 & 0.6 & 100 & 2552 \\
\hline Total & & 98.12 & 1.28 & 0.6 & 100 & 3122 \\
\hline
\end{tabular}

Mobility in year $t$ is constructed from retrospective survey question of year $t+1$. Sample: Observations included in the wage rigidity estimation sample, i.e. individuals for whom wage data and other regressors are available in $\mathrm{t}$ and $\mathrm{t}-1$, external job stayers.

Internal job mobility rates in the table are calculated in the sample of external job stayers only. With respect to the potential under estimation of internal job mobility, the same remarks as for external job mobility apply. On average, internal job mobility rates and GDP growth rates are higher until 1992 and lower after that year. We checked whether a change of the survey questionnaire in 1994 (which asks for 1993 mobility retrospectively) could be responsible for the somewhat sharp drop in internal job mobility after 1993. There was a change in the 1994 questionnaire. Before 1994 the survey question read „Has your job situation changed since the beginning of [last year]? Please enter if any of the following applies to you, and if yes, when." The question included a list of possible job changes including "have changed position within the firm“. After 1993 the question read „Has your job situation changed since the beginning of [last year]?" Only if the answer is yes are respondents guided to a later question about the type of change. It might be that in the newer version of the questionnaire respondents do not think of positional 
changes within a firm as job changes, because the options are not listed explicitly. However, we think it is unlikely that this change would have the impact of more than halving job mobility numbers. We assume that the drop of internal job mobility in 1993 is real and has to do with the reaction on the business cycle. The sharp fall of internal job mobility rates in 1993 as compared to 1992 coincides with a sharp decrease of GDP growth without precedence in the sample period. Internal job mobility appears to be clearly procyclical. 


\section{Appendix C: The likelihood function}

The likelihood function for the estimation of the wage rigidity model is derived in more detail in Dickens and Goette (2002). The likelihood function is composed of the likelihood contributions of the different wage setting regimes weighted by the regime propensities. We derive two separate likelihood functions, one for the observations treated as measured exactly and the other for the observations treated as measured with errors.

In the following, the contributions of the regimes to the likelihood function are denominated by the following abbreviations:
F: flexible regime
U: unconstrained within the regime
$\mathrm{N}$ : nominal rigid regime
C: constrained within the regime
$R$ : real rigid regime

$\mathrm{X}$ : exactly measured

M: measured with measurement error

In the following, $w$ is observed wage growth, $c$ is expected notional wage growth, $r$ is the real rigidity threshold given as data, $\sigma_{e}$ and $\sigma_{m}$ are the standard deviations of notional wage growth and of the measurement error, $\varphi$ stands for the standard normal probability density function, $\Phi$ stands for the standard normal cumulative distribution function, and $\mathrm{I}(\cdot)$ is an indicator function that takes on the value 1 if the argument is true and 0 otherwise.

Expected notional wage growth $\mathrm{c}$ would equal $x^{\prime} \beta$ if notional wage growth were estimated within the rigidity model. In our estimation, the $75^{\text {th }}$ percentile of notional wage growth, $p 75$, is estimated by quantile regression outside the rigidity model. Expected notional wage growth, $c$, is derived from the $75^{\text {th }}$ percentile of the notional wage growth equation by means of the standard deviation of notional wage growth:

$c=p 75-z_{0.75} \cdot \sigma_{e}$

\section{The likelihood function for observations treated as exactly measured}

The likelihood contribution of the flexible regime without measurement error is

$$
\mathrm{FUX}=\frac{1}{\sigma_{\mathrm{e}}} \phi\left(\frac{\mathrm{w}-\mathrm{c}}{\sigma_{\mathrm{e}}}\right)
$$

In the flexible regime, wage setting is always unconstrained.

In the nominal rigid regime, wage setting can be constrained or unconstrained. In the nominal rigid regime without measurement error, positive values of observed wage growth are outcomes of the unconstrained case:

$$
\mathrm{NUX}=\frac{1}{\sigma_{\mathrm{e}}} \phi\left(\frac{\mathrm{w}-\mathrm{c}}{\sigma_{\mathrm{e}}}\right) \cdot \mathrm{I}(\mathrm{w}>0)
$$

Observed wage growth observations of zero in this regime are outcomes of the constrained case:

$$
\mathrm{NCX}=\Phi\left(\frac{-\mathrm{x}^{\prime} \beta}{\sigma_{\mathrm{e}}}\right) \cdot \mathrm{I}(\mathrm{w}=0)
$$

Negative wage growth observations have zero probability in this regime.

In the real rigid regime without measurement error the unconstrained case applied to wage growth observations above the rigidity threshold, $r_{i t}$, the constrained case applied to observations at the threshold: 


$$
\begin{aligned}
& \operatorname{RUX}=\frac{1}{\sigma_{\mathrm{e}}} \phi\left(\frac{\mathrm{w}-\mathrm{c}}{\sigma_{\mathrm{e}}}\right) \cdot \mathrm{I}(\mathrm{w}>\mathrm{r}) \\
& \mathrm{RCX}=\Phi\left(\frac{\mathrm{r}-\mathrm{c}}{\sigma_{\mathrm{e}}}\right) \cdot \mathrm{I}(\mathrm{w}=\mathrm{r})
\end{aligned}
$$

Wage growth observations below the rigidity threshold have zero probability in this regime.

The likelihood function for observations treated as exactly measured is the sum of the regimes weighted by the regime probabilities:

$$
L L_{X}=p_{f} \cdot[F U X]+p_{n} \cdot[N U X+N C X]+p_{r} \cdot[R U X+R C X]
$$

\section{The likelihood function for observations treated with measurement error}

The likelihood contribution of the flexible regime with measurement error is given by a bivariate normal distribution of the notional wage growth error term and the measurement error term:

$$
\mathrm{FUM}=\frac{1}{\sqrt{\sigma_{\mathrm{e}}^{2}+\sigma_{\mathrm{m}}^{2}}} \phi\left(\frac{\mathrm{w}-\mathrm{c}}{\sqrt{\sigma_{\mathrm{e}}^{2}+\sigma_{\mathrm{m}}^{2}}}\right)
$$

In the nominal rigid regime, a distinction must be made again between the unconstrained and the constrained regime:

$$
\begin{aligned}
& N U M=\left[1-\Phi\left(\frac{-c-\frac{\sigma_{e}^{2}}{\sigma_{e}^{2}+\sigma_{m}^{2}}(w-c)}{\sqrt{\sigma_{e}^{2}+\frac{\sigma_{e}^{4}}{\sigma_{e}^{2}+\sigma_{m}^{2}}}}\right)\right] \cdot \frac{1}{\sqrt{\sigma_{e}^{2}+\sigma_{m}^{2}}} \phi\left(\frac{w-c}{\sqrt{\sigma_{e}^{2}+\sigma_{m}^{2}}}\right) \\
& \mathrm{NCM}=\Phi\left(\frac{-\mathrm{c}}{\sigma_{\mathrm{e}}}\right) \cdot \frac{1}{\sigma_{\mathrm{m}}} \phi\left(\frac{\mathrm{w}}{\sigma_{\mathrm{m}}}\right)
\end{aligned}
$$

In the real rigid regime with measurement error, likelihood contributions are:

$$
\begin{aligned}
R U M & =\left[1-\Phi\left(\frac{r-c-\frac{\sigma_{e}^{2}}{\sigma_{e}^{2}+\sigma_{m}^{2}}(w-c)}{\sqrt{\sigma_{e}^{2}+\frac{\sigma_{e}^{4}}{\sigma_{e}^{2}+\sigma_{m}^{2}}}}\right)\right] \cdot \frac{1}{\sqrt{\sigma_{e}^{2}+\sigma_{m}^{2}}} \phi\left(\frac{w-c}{\sqrt{\sigma_{e}^{2}+\sigma_{m}^{2}}}\right) \\
\mathrm{RCM} & =\Phi\left(\frac{\mathrm{r}-\mathrm{c}}{\sigma_{\mathrm{e}}}\right) \cdot \frac{1}{\sigma_{\mathrm{m}}} \phi\left(\frac{\mathrm{w}-\mathrm{r}}{\sigma_{\mathrm{m}}}\right)
\end{aligned}
$$

The likelihood function for observations treated as measured with error is the sum of the regimes weighted by the regime probabilities:

$$
L L_{M}=p_{f} \cdot[F U M]+p_{n} \cdot[N U M+N C M]+p_{r} \cdot[R U M+R C M]
$$




\section{Tables}

Table 3: 0.75 quantile regression of notional wage growth

\begin{tabular}{|c|c|c|c|c|c|}
\hline \multicolumn{6}{|c|}{ Dependent Variable: wage growth (diff. In log wages) } \\
\hline \multicolumn{2}{|c|}{$\begin{array}{l}\text { Iterations: } \\
\text { Sum of abs. weighted deviations: } \\
\text { Raw sum of deviations }\end{array}$} & $\begin{array}{l}781 \\
3276.89 \\
3360.86\end{array}$ & $\begin{array}{l}\text { Min sum of deviations } \\
\text { Pseudo R2 } \\
\text { No. of observations } \\
\end{array}$ & \multicolumn{2}{|c|}{$\begin{array}{l}3276.887 \\
0.025 \\
37734\end{array}$} \\
\hline & Coef. & s.e. & & Coef. & S.e. \\
\hline$\overline{\text { male }}$ & $0.006^{* \star \star}$ & 0.002 & industry 5 & -0.081 & 0.050 \\
\hline foreign & 0.004 & 0.003 & industry 7 & -0.094 & 0.066 \\
\hline schooling & $-0.002^{\star \star \star}$ & 0.001 & industry 8 & -0.051 & 0.043 \\
\hline tenure $>1<=2$ & $-0.051^{\star * *}$ & 0.005 & industry 9 & -0.017 & 0.024 \\
\hline tenure $>2<=3$ & $-0.057^{\star \star \star}$ & 0.006 & industry 10 & -0.015 & 0.053 \\
\hline tenure $>3<=4$ & $-0.061^{* * *}$ & 0.006 & industry 11 & -0.044 * & 0.026 \\
\hline tenure $>4<=5$ & $-0.072^{* * *}$ & 0.006 & industry 12 & -0.042 & 0.026 \\
\hline tenure $>5<=7$ & $-0.069 * * \star$ & 0.005 & industry 13 & $-0.078 *$ & 0.043 \\
\hline tenure $>7<=10$ & $-0.073^{\star \star \star}$ & 0.005 & industry 14 & -0.021 & 0.025 \\
\hline tenure $>10<=20$ & $-0.080^{* * *}$ & 0.005 & industry 15 & -0.020 & 0.025 \\
\hline tenure $>20$ & $-0.082^{* * *}$ & 0.005 & industry 16 & -0.029 & 0.025 \\
\hline experience $>2<=5$ & 0.019 & 0.023 & industry 17 & 0.003 & 0.034 \\
\hline experience $>5<=8$ & 0.006 & 0.022 & industry 18 & -0.037 & 0.023 \\
\hline experience $>8<=10$ & -0.002 & 0.022 & industry 19 & -0.046 * & 0.025 \\
\hline experience $>10<=15$ & -0.010 & 0.022 & industry 20 & -0.036 & 0.025 \\
\hline experience $>15<=25$ & -0.015 & 0.022 & industry 21 & -0.026 & 0.024 \\
\hline experience $>25<=35$ & -0.027 & 0.022 & industry 22 & -0.033 & 0.023 \\
\hline experience $>35<=45$ & -0.030 & 0.022 & industry 23 & -0.028 & 0.023 \\
\hline experience $>45$ & $-0.041^{*}$ & 0.024 & industry 24 & -0.013 & 0.041 \\
\hline months unempl. last year & -0.003 & 0.002 & industry 25 & -0.032 & 0.023 \\
\hline overtime $>0<=0.5$ & -0.007 & 0.008 & industry 26 & -0.033 & 0.026 \\
\hline overtime $>0.5<=1$ & $-0.017^{\star * *}$ & 0.005 & industry 27 & -0.030 & 0.024 \\
\hline overtime $>1 \quad<=2$ & $-0.015^{* * *}$ & 0.003 & industry 28 & -0.030 & 0.024 \\
\hline overtime $>2<=5$ & $-0.017^{\star \star \star}$ & 0.002 & industry 29 & -0.034 & 0.029 \\
\hline overtime $>5 \quad<=10$ & $-0.035^{* * *}$ & 0.003 & industry 30 & -0.020 & 0.026 \\
\hline overtime $>10<=15$ & $-0.049^{\star \star \star}$ & 0.006 & industry 31 & -0.065 & 0.043 \\
\hline overtime $>15<=20$ & $-0.078^{* * \star}$ & 0.010 & industry 32 & -0.043 * & 0.024 \\
\hline overtime $>20<=25$ & $-0.081^{* * *}$ & 0.014 & industry 33 & 0.002 & 0.033 \\
\hline overtime $>25$ & $-0.239 * \star \star$ & 0.057 & industry 34 & -0.031 & 0.023 \\
\hline firm size $>=20<200$ & $0.012^{* * \star}$ & 0.003 & industry 35 & -0.026 & 0.025 \\
\hline firm size $>=200<2000$ & $0.013^{\star \star \star}$ & 0.003 & industry 36 & -0.039 * & 0.024 \\
\hline firm size > 2000 & $0.017^{* * \star}$ & 0.003 & industry 37 & -0.030 & 0.023 \\
\hline intermediate status group & 0.002 & 0.002 & industry 38 & -0.046 * & 0.025 \\
\hline high status group & $0.024^{* \star \star}$ & 0.004 & industry 39 & -0.035 & 0.024 \\
\hline skill training last period & $0.015^{* *}$ & 0.007 & industry 40 & -0.012 & 0.047 \\
\hline East Germany & $0.016^{* * \star}$ & 0.004 & industry 41 & -0.005 & 0.037 \\
\hline South Germany & -0.001 & 0.002 & industry 42 & -0.043 * & 0.025 \\
\hline education parents & -0.0001 & 0.001 & industry 43 & $-0.041 *$ & 0.024 \\
\hline Diff. Unempl. Rate, t & $-0.004 *$ & 0.002 & industry 44 & -0.035 & 0.024 \\
\hline Diff. Unempl. Rate, t-1 & $-0.010^{* * *}$ & 0.002 & industry 45 & -0.032 & 0.024 \\
\hline Diff. Unempl. Rate, t-2 & $-0.004^{* *}$ & 0.002 & industry 52 & $-0.046^{* *}$ & 0.023 \\
\hline inflation & $-0.006^{* * *}$ & 0.002 & period $91-97$ & 0.011 ** & 0.004 \\
\hline inflation, $\mathrm{t}-1$ & $0.011^{* * *}$ & 0.002 & period $98-02$ & $-0.019^{* * *}$ & 0.003 \\
\hline inflation, t-2 & $-0.006^{* * *}$ & 0.002 & year 2002 & $0.014^{* * *}$ & 0.004 \\
\hline industry 4 & -0.035 & 0.025 & constant & $0.255^{* * *}$ & 0.033 \\
\hline
\end{tabular}

Coefficient significant at the ${ }^{* \star *} 1 \%-$ level, ${ }^{* \star} 5 \%$-level, ${ }^{*} 10 \%$ level. 
Table 4: Two-step ML estimation of the wage rigidity model

(a) FIRST STEP (pn=0)

\begin{tabular}{|c|c|c|c|}
\hline $\bar{N}$ & 36944 & & \\
\hline LL & 22136.5 & & \\
\hline Wald chi2(11) & 200.01 & & \\
\hline \multirow{2}{*}{$\sigma_{e}$ equation } & \multicolumn{3}{|c|}{ Significance } \\
\hline & Coeff. (i) (ii) & (iii) & s.e. (i) \\
\hline age & -0.0009 & & 0.0006 \\
\hline male & $-0.037^{* *}$ & * & 0.0144 \\
\hline schooling & $-0.011^{* * * * * *}$ & $* * *$ & 0.0034 \\
\hline public sector & $-0.035^{* *}$ & ** & 0.0174 \\
\hline intermediate status group & $-0.091^{* * * * * *}$ & $* * *$ & 0.0150 \\
\hline high status group & $-0.060^{* *} * *$ & *** & 0.0261 \\
\hline external stayer $\mathrm{t}-1$ & $-0.215^{* * * * * *}$ & $* * *$ & 0.0216 \\
\hline constant & $-1.404^{* * * * * *}$ & $* * *$ & 0.0468 \\
\hline
\end{tabular}

\begin{tabular}{llll}
\multicolumn{1}{c}{$\sigma_{m}$ equation } & & \\
\hline schooling & -0.009 & & 0.0112 \\
intermediate status group & 0.002 & & 0.0530 \\
high status group & 0.041 & & 0.0851 \\
wage rounded to 100 & $0.351^{* * * * * * * *}$ & 0.0323 \\
wage rounded to 1000 & $0.209^{* * * * * * * *}$ & 0.0495 \\
constant & $-3.169 * * * * * *$ & 0.1217
\end{tabular}

\begin{tabular}{|c|c|c|c|c|}
\hline male & $-0.474^{* * *}$ & $* * *$ & $* \star \star$ & 0.0667 \\
\hline schooling & $0.075^{* * *}$ & $* * *$ & $* * *$ & 0.0221 \\
\hline experience & -0.003 & & & 0.0035 \\
\hline tenure & $0.017^{* * *}$ & $* * *$ & $* * *$ & 0.0033 \\
\hline public sector & $0.564^{* * *}$ & $* * *$ & $* \star \star$ & 0.0721 \\
\hline firm size $>=20<200$ & -0.065 & & & 0.0825 \\
\hline firm size $>=200<2000$ & $0.147^{*}$ & & ** & 0.0828 \\
\hline firm size $>2000$ & 0.112 & & & 0.0836 \\
\hline intermediate status group & 0.051 & & & 0.0981 \\
\hline high status group & -0.067 & & & 0.1647 \\
\hline promotion $\mathrm{t}-1$ & 0.185 & & & 0.2243 \\
\hline transfer t-1 & $-0.561 *$ & * & ** & 0.3276 \\
\hline firm closure t-1 & -1.782 & * & & 1.1792 \\
\hline endcontract $\mathrm{t}-1$ & $-13.199 * * *$ & $* * *$ & $\star \star \star *$ & 0.817 \\
\hline othermove $\mathrm{t}-1$ & $-1.987 *$ & ** & ** & 1.1206 \\
\hline quit t-1 & -1.482 *** & 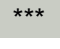 & $\star \star \star \star ~$ & 0.375 \\
\hline layoff t-1 & -3.630 & & & 3.4898 \\
\hline nominal GDP growth & $4.176^{* \star \star}$ & $* \star *$ & & 1.132 \\
\hline constant & $-1.107^{* * *}$ & 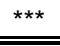 & $\star * *$ & 0.2709 \\
\hline
\end{tabular}

(b) SECOND STEP (pr=fix)

\begin{tabular}{lr}
\hline \hline $\mathrm{N}$ & 36944 \\
$\mathrm{LL}$ & 21763.7 \\
Wald chi2(11) & 331.6
\end{tabular}

\begin{tabular}{|c|c|c|c|c|}
\hline \multirow[b]{2}{*}{$\sigma_{e}$ equation } & \multicolumn{4}{|c|}{ Significance } \\
\hline & Coeff. (i) & (ii) & (iii) & s.e. (i) \\
\hline age & $-0.001^{* * *}$ & $* *$ & $\star *$ & 0.0005 \\
\hline male & -0.023 * & & & 0.012 \\
\hline schooling & $-0.015^{* * *}$ & $* \star *$ & $* \star *$ & 0.003 \\
\hline public sector & $-0.082^{* * *}$ & ** & $* * *$ & 0.015 \\
\hline intermediate status group & -0.102 *** & $* * *$ & $* * *$ & 0.014 \\
\hline high status group & $-0.060 * *$ & $* \star *$ & $* * *$ & 0.025 \\
\hline external stayer t-1 & $-0.237^{\star \star *}$ & $\star \star \star *$ & $* \star *$ & 0.019 \\
\hline constant & $-1.353^{* * *}$ & $* \star \star$ & $\star \star \star *$ & 0.046 \\
\hline
\end{tabular}

$$
\sigma_{m} \text { equation }
$$

\begin{tabular}{|c|c|c|}
\hline schooling & -0.005 & 0.010 \\
\hline intermediate status group & 0.017 & 0.046 \\
\hline high status group & 0.047 & 0.077 \\
\hline wage rounded to 100 & $0.325^{* * * * * * * * *}$ & 0.039 \\
\hline wage rounded to 1000 & $0.228^{* * * * * * * * *}$ & 0.050 \\
\hline constant & $-3.157^{* \star *} \quad \star * * * * *$ & 0.112 \\
\hline
\end{tabular}

\begin{tabular}{|c|c|c|c|}
\hline retail & reference group & & \\
\hline mining & $4.280^{* * * *}$ & ** & 1.204 \\
\hline manufacturing & $-10.750^{* * * * * *}$ & *** & 1.191 \\
\hline ressource processing & $-11.440 * * * * \star *$ & $\star \star \star ~$ & 1.204 \\
\hline transp. \& communication & 0.227 & & 2.405 \\
\hline building sector & 1.281 & * & 1.064 \\
\hline services & $-14.445^{* * * * * *}$ & *** & 2.278 \\
\hline credit and insurance & $3.991 * * * *$ & $\star \star \star ~$ & 1.407 \\
\hline public utilities & 0.932 & ** & 1.214 \\
\hline nominal GDP growth & $-51.647 *$ & ** & 30.46 \\
\hline constant & $17.344^{* * * * * *}$ & *** & 2.670 \\
\hline \multicolumn{4}{|c|}{$\begin{array}{l}\text { Coefficient significant at the }{ }^{* * *} 1 \% \text {-level, }{ }^{* *} 5 \% \text {-level, }{ }^{*} 10 \% \text { - } \\
\text { level. }\end{array}$} \\
\hline \multicolumn{4}{|c|}{$\begin{array}{l}\text { Significance level based on } \\
\text { (i) robust "Huber/White/sandwich" standard errors (reported } \\
\text { in the table), } \\
\text { (ii) standard errors adjusted for within group error term } \\
\text { correlation, clustering on industry, } \\
\text { (iii) standard errors adjusted for within group error term } \\
\text { correlation, clustering on year. }\end{array}$} \\
\hline
\end{tabular}


Table 5: Overview of average parameter values of the wage rigidity model

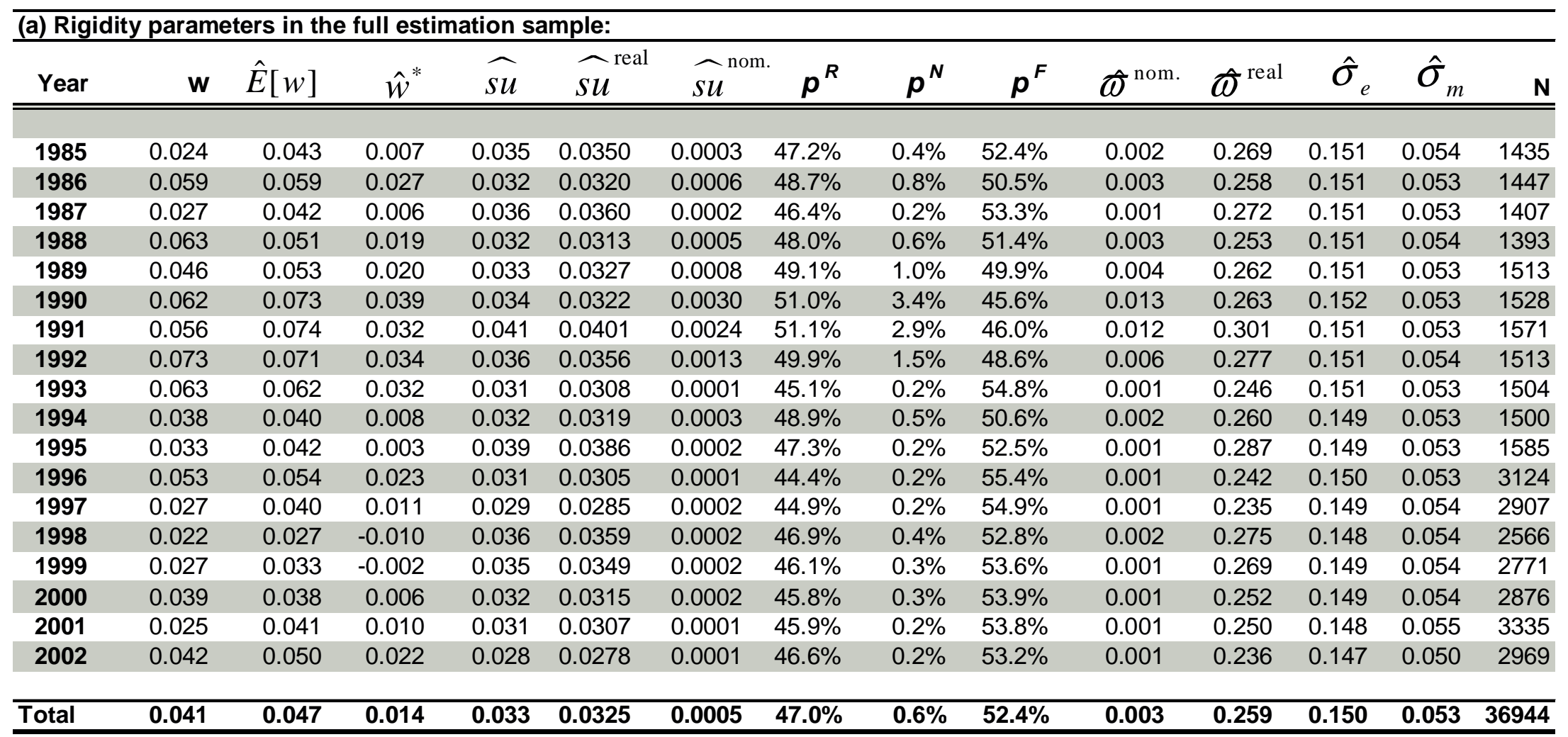

(b) Average rigidity parameters in the sample of workers who had no change in the amount of overtime hours:

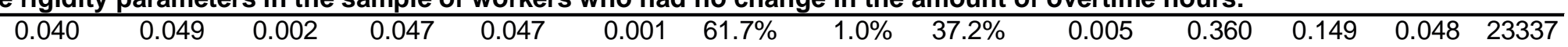

w: observed wage growth

$\hat{E}[w]$ : predicted actual wage growth

$\mathrm{w}^{*}$ : notional wage growth

sû: wage sweep-up

sû́ ${ }^{\text {real }}$ : wage sweep-up due to real wage rigidity sûn $^{\text {nominal }}$ : wage sweep-up due to nominal wage rigidity $p^{R}, p^{N}, p^{F}$ : propensities of wage setting regimes $\omega^{\text {nom.: }}$ fraction affected by nominal wage rigidity $\omega^{\text {real }}$ : fraction affected by real wage rigidity

$\mathrm{P}$ [wage cut]: fraction receiving wage cuts $\sigma_{\mathrm{e}}:$ std. dev. of notional wage growth $\sigma_{\mathrm{m}}:$ std. dev. of measurement error

$\mathrm{N}$ : no. of observations 
Table 6: Distribution of the wage sweep-up in the estimation sample

\begin{tabular}{rrrrrrr}
\hline \multicolumn{7}{c}{ Percentiles } \\
\hline 5 th & 10 th & 25th & 50 th & 75 th & 90th & 95th \\
0.015 & 0.019 & 0.025 & 0.032 & 0.040 & 0.048 & 0.052 \\
\hline
\end{tabular}

Table 7: Heterogeneity of the wage sweep-up - bivariate tabulation

\begin{tabular}{|c|c|c|c|c|c|}
\hline & $\begin{array}{r}\text { Mean } \\
\text { eep-up }\end{array}$ & $\underline{N}$ & & $\begin{array}{l}\text { Mean } \\
\text { ep-up }\end{array}$ & $\mathbf{N}$ \\
\hline \multicolumn{3}{|c|}{ Sex } & \multicolumn{3}{|c|}{ Experience } \\
\hline$\overline{\text { Female }}$ & 0.039 & 12252 & $<=2$ years & 0.030 & $\overline{59}$ \\
\hline Male & 0.030 & 24692 & $>2-5$ years & 0.023 & 889 \\
\hline \multicolumn{3}{|c|}{ Foreign } & $\begin{array}{l}>5-8 \text { years } \\
>8-10 \text { years }\end{array}$ & $\begin{array}{l}0.025 \\
0.027\end{array}$ & $\begin{array}{l}2300 \\
1904\end{array}$ \\
\hline German & 0.033 & 30197 & $>10-15$ years & 0.029 & 5449 \\
\hline Foreign & 0.031 & 6747 & $>15-25$ years & 0.032 & 10683 \\
\hline & & & $>25$ - 35 years & 0.037 & 9460 \\
\hline \multicolumn{3}{|c|}{ Firm Size } & $>35-45$ years & 0.038 & 5878 \\
\hline$<20$ & 0.030 & 5791 & $>45$ years & 0.039 & 322 \\
\hline$>=20<200$ & 0.029 & 9930 & & & \\
\hline$>=200<2000$ & 0.035 & 9525 & & & \\
\hline \multirow[t]{2}{*}{$>2000$} & 0.035 & 11698 & Worke & us grou & \\
\hline & & & & 0.035 & 10194 \\
\hline \multicolumn{3}{|c|}{ Mobility in $\mathrm{t}-1$} & intermediate & 0.033 & 21855 \\
\hline Stayer (ext. \& int.) & 0.034 & 34557 & high status group & 0.030 & 4895 \\
\hline Quit & 0.011 & 976 & & & \\
\hline Layoff & 0.002 & 295 & & & \\
\hline Firm closure & 0.000 & 116 & Years & hooling & \\
\hline End temp. contract & 0.009 & 105 & 7 & 0.032 & 1286 \\
\hline Other external & 0.007 & 167 & 8.5 & 0.027 & 176 \\
\hline Promotion & 0.037 & 493 & 9 & 0.033 & 4757 \\
\hline \multirow[t]{2}{*}{ Transfer } & 0.027 & 235 & 10 & 0.032 & 1109 \\
\hline & & & 10.5 & 0.033 & 9849 \\
\hline \multicolumn{3}{|c|}{ Public Sector } & 11 & 0.033 & 3318 \\
\hline$\overline{\text { Private Sector }}$ & 0.031 & 27880 & 11.5 & 0.033 & 7077 \\
\hline \multirow[t]{2}{*}{ Public Sector } & 0.040 & 9064 & 12 & 0.032 & 2589 \\
\hline & & & 13 & 0.034 & 997 \\
\hline \multicolumn{2}{|c|}{ Tenure } & & 13.5 & 0.031 & 423 \\
\hline$<1$ year & 0.009 & 1690 & 14 & 0.031 & 531 \\
\hline 1 - 2 years & 0.024 & 2446 & 14.5 & 0.034 & 895 \\
\hline $2-3$ years & 0.027 & 2326 & 15 & 0.032 & 1181 \\
\hline 3 - 4 years & 0.028 & 2215 & 16 & 0.035 & 785 \\
\hline 4 - 5 years & 0.032 & 2126 & 17 & 0.031 & 103 \\
\hline $5-7$ years & 0.031 & 4057 & 18 & 0.034 & 1868 \\
\hline $7-10$ years & 0.033 & 4733 & & & \\
\hline $10-20$ years & 0.036 & 9622 & & & \\
\hline \multirow[t]{2}{*}{$>20$ years } & 0.041 & 7729 & & & \\
\hline & & & Total & 0.033 & 36944 \\
\hline
\end{tabular}


Table 8: Heterogeneity of the wage sweep-up - multivariate regression

\section{Dependent variable: WAGE SWEEP-UP (OLS regression)}

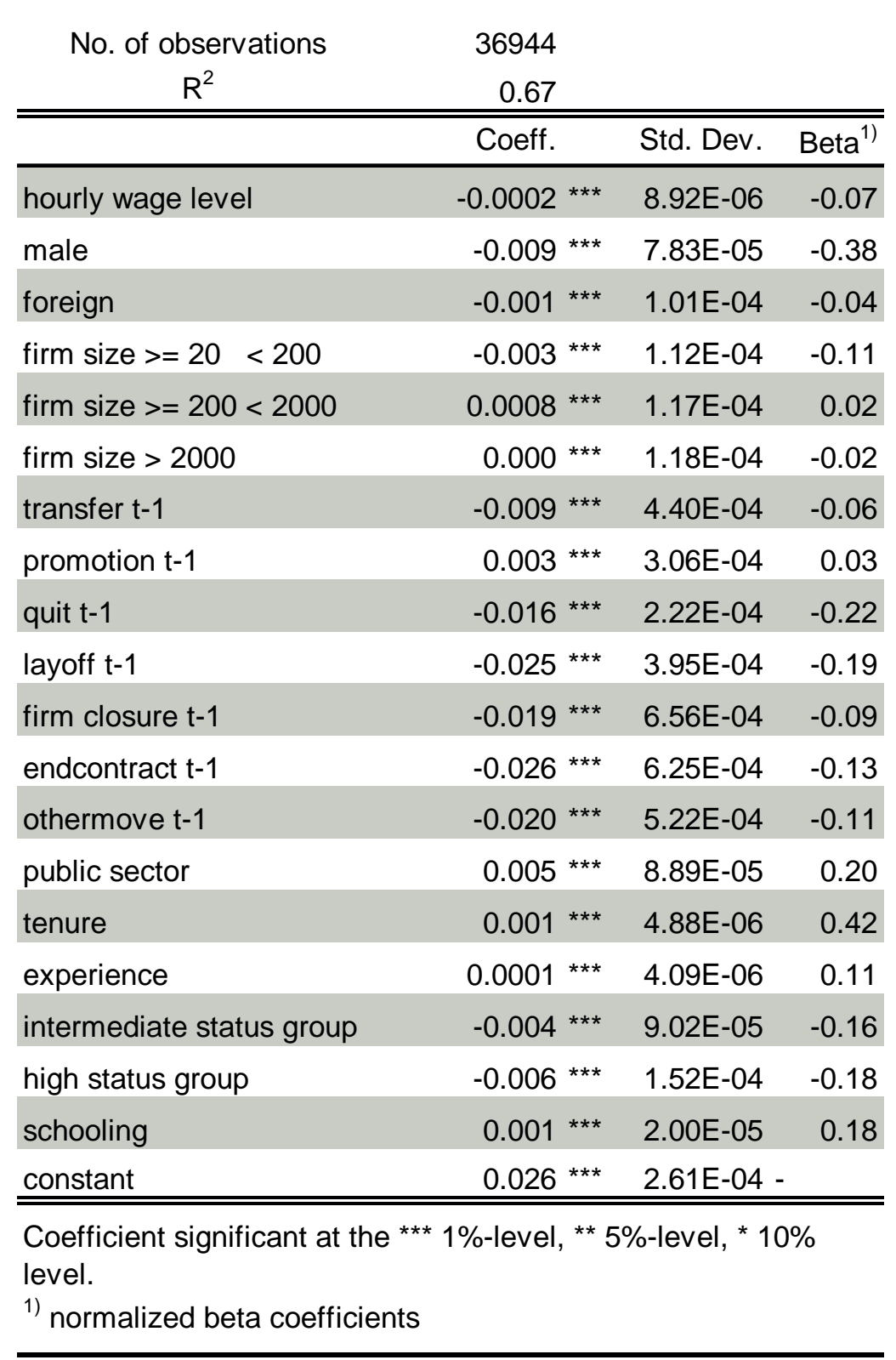


Table 9: Wage sweep-up by reported subjective probability of job mobility events

\begin{tabular}{|c|c|c|c|c|c|}
\hline & $\begin{array}{l}\text { Mean } \\
\text { eep-up }\end{array}$ & \multirow[t]{2}{*}{$\mathbf{N}$} & \multicolumn{3}{|c|}{$\begin{array}{r}\text { Mean } \\
\text { sweep-up }\end{array}$} \\
\hline \multicolumn{2}{|c|}{ Subjective probability of job loss ${ }^{\text {a) }}$} & & \multicolumn{3}{|c|}{ Subjective probability of job search ${ }^{\text {a) }}$} \\
\hline Certain & 0.032 & 319 & Certain & 0.028 & 722 \\
\hline Probable & 0.031 & 1655 & Probable & 0.029 & 2154 \\
\hline Probably not & 0.032 & 9849 & Probably not & 0.032 & 5849 \\
\hline Unlikely & 0.036 & 8783 & Unlikely & 0.036 & 11901 \\
\hline Total & 0.034 & 20606 & Total & 0.034 & 20626 \\
\hline \multicolumn{6}{|c|}{ Subjective probability of promotion ${ }^{\text {a) }}$} \\
\hline Certain & 0.032 & 390 & & & \\
\hline Probable & 0.031 & 3354 & & & \\
\hline Probably not & 0.033 & 7906 & \multirow{3}{*}{\multicolumn{3}{|c|}{$\begin{array}{l}\text { a) Not available for all observations of the } \\
\text { sample (especially not available for waves } \\
1986,1988,1990,1997,2002)\end{array}$}} \\
\hline Unlikely & 0.035 & 8971 & & & \\
\hline$\overline{\text { Total }}$ & 0.034 & 20621 & & & \\
\hline
\end{tabular}


Table 10: Probit regression of quits

Dependent variable: QUIT $t+1,1=$ yes $0=$ no

\begin{tabular}{|c|c|c|c|c|c|c|}
\hline \multicolumn{2}{|c|}{ No. of observations } & 34300 & & & & \\
\hline \multirow{2}{*}{\multicolumn{2}{|c|}{$\begin{array}{l}\text { P-Val. Wald test of joint significance } \\
\text { P-Val }\end{array}$}} & 0 & & & & \\
\hline & & 0 & & & & \\
\hline \multirow{2}{*}{\multicolumn{2}{|c|}{$\begin{array}{c}\text { Sample probability of } y=1 \\
\text { Mean predicted probability of } y=1\end{array}$}} & $2.96 \%$ & & & & \\
\hline & & $2.96 \%$ & & & & \\
\hline \multicolumn{2}{|c|}{ Probability of $y=1$ predicted at means } & $1.29 \%$ & & & & \\
\hline & \multirow{2}{*}{$\begin{array}{c}\text { Marginal } \\
\text { effect at } \\
\text { means }\end{array}$} & \multicolumn{2}{|c|}{ Mean effect } & \multicolumn{3}{|c|}{ Variance effect } \\
\hline & & $\begin{array}{l}\text { Coeff. } \\
\text { (beta) }\end{array}$ & $\begin{array}{l}\text { Robust } \\
\text { Std. Dev. }\end{array}$ & $\begin{array}{r}\text { Coeff. } \\
\text { (gamma) }\end{array}$ & & $\begin{array}{l}\text { Robust } \\
\text { Std. Dev. }\end{array}$ \\
\hline hourly wage level & $-0.02 \%$ & -0.007 & 0.005 & - & - & - \\
\hline wage sweep-up * 100 & $-0.1 \%$ & -0.030 & 0.020 & - & - & - \\
\hline foreign & $-0.7 \%$ & 0.236 ** & 0.109 & -0.185 & *** & 0.069 \\
\hline male & $-0.2 \%$ & -0.048 & 0.038 & - & - & - \\
\hline schooling & $0.1 \%$ & $0.027^{\star * \star}$ & 0.008 & - & - & - \\
\hline number skill trainings & $0.2 \%$ & $0.051^{* *}$ & 0.023 & - & - & - \\
\hline tenure & $-0.1 \%$ & $-0.098^{* * *}$ & 0.013 & 0.020 & $* * *$ & 0.003 \\
\hline firm size $>=20<200$ & $-0.7 \%$ & $-0.211^{* * *}$ & 0.043 & - & - & - \\
\hline firm size $>=200<2000$ & $-1.1 \%$ & -0.002 & 0.110 & -0.143 & ** & 0.062 \\
\hline firm size > 2000 & $-1.4 \%$ & 0.063 & 0.109 & -0.215 & $* \star *$ & 0.063 \\
\hline number external moves & $0.1 \%$ & 0.023 * & 0.013 & - & - & - \\
\hline public sector & $-0.9 \%$ & $-0.279 * * *$ & 0.050 & - & - & - \\
\hline intermediate status group & $0.0 \%$ & -0.007 & 0.037 & - & - & - \\
\hline high status group & $-0.2 \%$ & -0.048 & 0.065 & - & - & - \\
\hline year 1985 & $-0.8 \%$ & $-0.226 * *$ & 0.108 & - & - & - \\
\hline year 1986 & $-0.6 \%$ & -0.186 * & 0.104 & - & - & - \\
\hline year 1987 & $-0.6 \%$ & -0.170 & 0.106 & - & - & - \\
\hline year 1988 & $-0.2 \%$ & -0.053 & 0.100 & - & - & - \\
\hline year 1989 & $0.2 \%$ & 0.064 & 0.094 & - & - & - \\
\hline year 1990 & $0.4 \%$ & 0.117 & 0.090 & - & - & - \\
\hline year 1991 & $0.5 \%$ & $0.153^{*}$ & 0.089 & - & - & - \\
\hline year 1992 & $0.0 \%$ & 0.006 & 0.091 & - & - & - \\
\hline year 1993 & $-0.7 \%$ & -0.210 ** & 0.101 & - & - & - \\
\hline year 1994 & $-0.3 \%$ & -0.103 & 0.099 & - & - & - \\
\hline year 1996 & $-1.1 \%$ & $-0.320^{* * *}$ & 0.087 & - & - & - \\
\hline year 1997 & $-1.2 \%$ & $-0.367 * * *$ & 0.088 & - & - & - \\
\hline year 1998 & $-0.5 \%$ & $-0.145 *$ & 0.085 & - & - & - \\
\hline year 1999 & $-0.3 \%$ & -0.098 & 0.083 & - & - & - \\
\hline year 2000 & $-0.6 \%$ & -0.190 ** & 0.085 & - & - & - \\
\hline year 2001 & $-0.7 \%$ & -0.208 ** & 0.084 & - & - & - \\
\hline year 2002 & $-1.4 \%$ & $-0.426 * * *$ & 0.093 & - & - & - \\
\hline constant & - & $-1.148^{* * *}$ & 0.126 & - & - & - \\
\hline
\end{tabular}

Coefficient significant at the ${ }^{* * *} 1 \%$-level, ${ }^{* *} 5 \%$-level, ${ }^{*} 10 \%$-level.

a) " $\mathrm{H}_{0}$ : parameters jointly insignificant" is rejected

b) " $\mathrm{H}_{0}$ : no heteroscedasticity" is rejected 
Table 11: Probit regression of quits, robustness check with different sample restrictions

Dependent variable: QUIT $t+1,1=$ yes $0=$ no

\begin{tabular}{|c|c|c|c|c|}
\hline \multirow[b]{2}{*}{ Sample restrictions } & \multicolumn{3}{|c|}{ Effect of wage sweep-up } & \multirow[b]{2}{*}{$\mathrm{N}$} \\
\hline & Coefficient & & $\begin{array}{c}\text { Standard } \\
\text { Dev. }\end{array}$ & \\
\hline none & -0.030 & & 0.020 & 34300 \\
\hline$\overline{\text { Female }}$ & -0.051 & & $\overline{0.031}$ & 11313 \\
\hline Male & -0.040 & * & 0.023 & 22987 \\
\hline Private sector & -0.028 & & 0.022 & 25804 \\
\hline Public sector & 0.019 & & 0.061 & 8496 \\
\hline Age $<30$ & -0.064 & & 0.045 & 6052 \\
\hline $30<=$ Age $<45$ & 0.003 & & 0.021 & 15343 \\
\hline Age $>=45$ & -0.034 & & 0.058 & 12905 \\
\hline Tenure $<5$ & -0.010 & & 0.024 & 9655 \\
\hline $5<=$ Tenure $<10$ & -0.033 & & $\overline{0.054}$ & 8180 \\
\hline Tenure $>=10$ & 0.004 & & $\overline{0.021}$ & 16465 \\
\hline Firm size $<20$ & -0.021 & & $\overline{0.040}$ & 5296 \\
\hline Firm size $<200$ & -0.010 & & 0.028 & 14487 \\
\hline Firm size $>=200$ & -0.062 & * & 0.037 & 19813 \\
\hline Firm size $>=2000$ & $\begin{array}{l}-0.078 \\
\end{array}$ & & 0.052 & 10940 \\
\hline West Germany & -0.013 & & 0.023 & 29869 \\
\hline East Germany & 0.010 & & 0.043 & 4431 \\
\hline Actual hours $<35$ & -0.054 & & 0.054 & 3442 \\
\hline Actual hours $>=35$ & -0.054 & 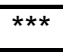 & 0.018 & 30858 \\
\hline Year $>=1994$ & -0.037 & * & 0.021 & 21827 \\
\hline Year < 1994 & -0.056 & * & 0.031 & 12473 \\
\hline
\end{tabular}

Other control variables included as in previous regression.

Coefficient significant at the ${ }^{* * *} 1 \%$-level, ${ }^{* *} 5 \%$-level, ${ }^{*} 10 \%$ level. 
Table 12: Probit regression of layoffs

\section{Dependent variable: LAYOFF $t+1,1=$ yes $0=$ no}

\begin{tabular}{|c|c|c|c|c|c|c|}
\hline \multicolumn{2}{|c|}{ No. of observations } & \multicolumn{2}{|l|}{34300} & & & \\
\hline \multicolumn{2}{|c|}{ P-Val. Wald test of joint significance a) } & 0 & & & & \\
\hline \multicolumn{2}{|c|}{ P-Val. LR test of heteroskedasticity ${ }^{b}$} & 0 & & & & \\
\hline \multirow{2}{*}{\multicolumn{2}{|c|}{$\begin{array}{c}\text { Sample probability of } y=1 \\
\text { Mean predicted probability of } y=1\end{array}$}} & $1.94 \%$ & & & & \\
\hline & & $1.91 \%$ & & & & \\
\hline \multicolumn{2}{|c|}{ Probability of $y=1$ predicted at means } & $0.85 \%$ & & & & \\
\hline & \multirow{2}{*}{$\begin{array}{l}\text { Marginal } \\
\text { effect at } \\
\text { means }\end{array}$} & \multicolumn{2}{|c|}{$\overline{\text { Mean effect (beta coeff.) }}$} & \multicolumn{3}{|c|}{$\begin{array}{l}\text { Variance effect (gamma } \\
\text { (amm }\end{array}$} \\
\hline & & $\begin{array}{l}\text { Coeff. } \\
\text { (beta) }\end{array}$ & $\begin{array}{l}\text { Robust } \\
\text { Std. Dev. }\end{array}$ & $\begin{array}{r}\text { Coeff. } \\
\text { (gamma) }\end{array}$ & & $\begin{array}{r}\text { Robust } \\
\text { Std. Dev. }\end{array}$ \\
\hline hourly wage level & $-0.1 \%$ & -0.005 & 0.008 & -0.019 & ** & 0.009 \\
\hline wage sweep-up * 100 & $-0.4 \%$ & $0.049^{* \star *}$ & 0.006 & -0.122 & *** & 0.015 \\
\hline foreign & $0.1 \%$ & 0.031 & 0.020 & - & - & - \\
\hline male & $-0.03 \%$ & -0.011 & 0.021 & - & - & 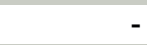 \\
\hline schooling & $0.002 \%$ & 0.001 & 0.005 & - & - & \\
\hline number skill trainings & $-0.1 \%$ & $-0.038 *$ & 0.020 & - & - & \\
\hline tenure & $-0.04 \%$ & $0.016^{\star \star *}$ & 0.003 & -0.024 & $* \star \star *$ & 0.003 \\
\hline firm size $>=20<200$ & $-0.1 \%$ & $-0.054^{* *}$ & 0.022 & - & - & 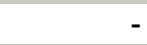 \\
\hline firm size $>=200<2000$ & $-0.2 \%$ & $-0.081^{* \star *}$ & 0.025 & - & - & \\
\hline firm size > 2000 & $-0.3 \%$ & $-0.120^{* \star *}$ & 0.032 & - & - & - \\
\hline number external moves & $0.04 \%$ & 0.016 * & 0.008 & - & - & \\
\hline public sector & $-0.3 \%$ & -0.109 ** & 0.045 & - & - & - \\
\hline intermediate status group & $-0.1 \%$ & $-0.056 * * *$ & 0.020 & - & - & \\
\hline high status group & $0.1 \%$ & 0.024 & 0.032 & - & - & \\
\hline year 1985 & $-0.1 \%$ & -0.052 & 0.055 & - & - & \\
\hline year 1986 & $-0.2 \%$ & -0.084 & 0.053 & - & - & \\
\hline year 1987 & $-0.3 \%$ & $-0.144 * *$ & 0.063 & - & - & \\
\hline year 1988 & $-0.4 \%$ & $-0.162 * *$ & 0.069 & - & - & \\
\hline year 1989 & $-0.4 \%$ & $-0.178 * * *$ & 0.066 & - & - & \\
\hline year 1990 & $-0.4 \%$ & $-0.167^{\star \star \star *}$ & 0.063 & - & - & \\
\hline year 1991 & $-0.1 \%$ & -0.053 & 0.060 & - & - & \\
\hline year 1992 & $-0.6 \%$ & $-0.245^{* * *}$ & 0.075 & - & - & S \\
\hline year 1993 & $0.1 \%$ & 0.045 & 0.045 & - & - & \\
\hline year 1994 & $-0.04 \%$ & -0.015 & 0.049 & - & - & - \\
\hline year 1996 & $0.2 \%$ & 0.074 * & 0.040 & - & - & \\
\hline year 1997 & $0.1 \%$ & 0.048 & 0.042 & - & - & - \\
\hline year 1998 & $0.3 \%$ & $0.145^{* * *}$ & 0.045 & - & - & - \\
\hline year 1999 & $0.1 \%$ & 0.058 & 0.041 & - & - & - \\
\hline year 2000 & $0.02 \%$ & 0.009 & 0.042 & - & - & - \\
\hline year 2001 & $0.04 \%$ & 0.018 & 0.041 & - & - & - \\
\hline year 2002 & $0.04 \%$ & 0.017 & 0.043 & - & - & - \\
\hline mining ${ }^{c)}$ & $0.2 \%$ & 0.079 & 0.053 & - & - & 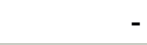 \\
\hline manufacturing & $0.1 \%$ & $0.047^{\star \star}$ & 0.023 & - & - & \\
\hline ressource processing & $0.1 \%$ & 0.033 & 0.032 & - & - & \\
\hline transp. \& communication & $0.1 \%$ & 0.023 & 0.039 & - & - & \\
\hline building sector & $0.3 \%$ & $0.131^{\star \star *}$ & 0.032 & - & - & \\
\hline services & $0.3 \%$ & $0.134^{\star \star}$ & 0.067 & - & - & \\
\hline credit and insurance & $-0.3 \%$ & $-0.146 *$ & 0.076 & - & - & \\
\hline public utilities & $-0.1 \%$ & -0.049 & 0.060 & - & - & \\
\hline constant & - & $-1.118^{* * *}$ & 0.087 & - & - & \\
\hline
\end{tabular}

Coefficient significant at the ${ }^{* * *} 1 \%$-level, ${ }^{* *} 5 \%$-level, ${ }^{*} 10 \%$-level.
a) " $\mathrm{H}_{0}$ : parameters jointly insignificant" is rejected
b) " $\mathrm{H}_{0}$ : no heteroscedasticity" is rejected
c) reference sector: retail 
Table 13: Distribution of the marginal effect of the wage sweep-up on the probability of a layoff

\begin{tabular}{|c|c|c|c|c|c|}
\hline \multicolumn{5}{|c|}{ Percentiles of marginal effect in percentage points } & \multirow{2}{*}{$\begin{array}{l}\text { Fraction with } \\
\text { m. effect }>0\end{array}$} \\
\hline 5 th & 25th & 50th & 75th & 95th & \\
\hline$-1.30 \%$ & $-0.82 \%$ & $-0.43 \%$ & $-0.14 \%$ & $-0.01 \%$ & 0.009 \\
\hline
\end{tabular}


Table 14: Probit regression of promotions

\section{Dependent variable: PROMOTION t+1, 1=yes $0=$ no}

\begin{tabular}{|c|c|c|c|c|c|c|}
\hline \multicolumn{2}{|c|}{ No. of observations } & 31221 & & & & \\
\hline \multirow{2}{*}{\multicolumn{2}{|c|}{$\begin{array}{l}\text { P-Val. Wald test of joint significance }{ }^{\text {a) }} \\
\text { P-Val. LR test of heteroskedasticity }{ }^{\text {b) }}\end{array}$}} & 0 & & & & \\
\hline & & 0.0008 & & & & \\
\hline \multicolumn{2}{|c|}{ Sample probability of $y=1$} & $1.28 \%$ & & & & \\
\hline \multicolumn{2}{|c|}{ Mean predicted probability of $y=1$} & $1.28 \%$ & & & & \\
\hline \multicolumn{2}{|c|}{ Probability of $y=1$ predicted at means } & $0.69 \%$ & & & & \\
\hline & \multirow{2}{*}{$\begin{array}{c}\text { Marginal } \\
\text { effect at } \\
\text { means }\end{array}$} & \multicolumn{2}{|c|}{ Mean effect (beta coeff.) } & \multicolumn{3}{|c|}{ Variance effect (gamma } \\
\hline & & $\begin{array}{l}\text { Coeff. } \\
\text { (beta) }\end{array}$ & $\begin{array}{l}\text { Robust } \\
\text { Std. Dev. }\end{array}$ & $\begin{array}{r}\text { Coeff. } \\
\text { (gamma) }\end{array}$ & & $\begin{array}{l}\text { Robust } \\
\text { Std. Dev. }\end{array}$ \\
\hline hourly wage level & $-0.03 \%$ & $-0.095^{\star \star}$ & 0.044 & 0.019 & ** & 0.008 \\
\hline wage sweep-up * 100 & $-0.1 \%$ & $-0.264^{\star \star}$ & 0.107 & 0.050 & ** & 0.025 \\
\hline foreign & $-0.7 \%$ & $-0.348^{* * *}$ & 0.120 & - & - & - \\
\hline male & $-0.1 \%$ & -0.042 & 0.084 & - & - & - \\
\hline schooling & $0.2 \%$ & $0.100 * * *$ & 0.022 & - & - & - \\
\hline skill training last period & $0.5 \%$ & -3.543 & 3.558 & 1.046 & * & 0.548 \\
\hline tenure & $-0.03 \%$ & $-0.017^{* * *}$ & 0.006 & - & - & - \\
\hline firm size $>=20<200$ & $0.6 \%$ & $0.305^{*}$ & 0.170 & - & - & - \\
\hline firm size $>=200<2000$ & $1.7 \%$ & $0.886^{* * *}$ & 0.193 & - & - & - \\
\hline firm size > 2000 & $2.2 \%$ & $1.147^{* * *}$ & 0.214 & - & - & - \\
\hline number external moves & $-0.1 \%$ & $-0.073 *$ & 0.044 & - & - & - \\
\hline public sector & $0.5 \%$ & $0.237^{* * *}$ & 0.083 & - & - & - \\
\hline intermediate status group & $0.4 \%$ & $0.230^{* * *}$ & 0.089 & - & - & - \\
\hline high status group & $0.5 \%$ & 0.286 * & 0.148 & - & - & - \\
\hline year 1985 & $1.0 \%$ & $0.503^{* *}$ & 0.244 & - & - & - \\
\hline year 1986 & $1.0 \%$ & $0.502 * *$ & 0.245 & - & - & - \\
\hline year 1987 & $0.6 \%$ & 0.297 & 0.255 & - & - & - \\
\hline year 1988 & $1.0 \%$ & $0.507^{* \star}$ & 0.251 & - & - & - \\
\hline year 1989 & $0.7 \%$ & 0.367 & 0.245 & - & - & - \\
\hline year 1990 & $0.6 \%$ & 0.335 & 0.249 & - & - & - \\
\hline year 1991 & $1.0 \%$ & $0.514^{* *}$ & 0.251 & - & - & - \\
\hline year 1992 & $1.2 \%$ & $0.605^{* *}$ & 0.253 & - & - & - \\
\hline year 1993 & $-0.6 \%$ & -0.297 & 0.291 & - & - & - \\
\hline year 1994 & $0.4 \%$ & 0.224 & 0.251 & - & - & - \\
\hline year 1996 & $0.0 \%$ & 0.026 & 0.231 & - & - & - \\
\hline year 1997 & $-0.1 \%$ & -0.044 & 0.238 & - & - & - \\
\hline year 1998 & $-0.1 \%$ & -0.066 & 0.239 & - & - & - \\
\hline year 1999 & $0.02 \%$ & 0.009 & 0.239 & - & - & - \\
\hline year 2000 & $-0.3 \%$ & -0.158 & 0.245 & - & - & - \\
\hline year 2001 & $-0.5 \%$ & -0.239 & 0.242 & - & - & - \\
\hline year 2002 & $0.3 \%$ & 0.150 & 0.236 & - & - & - \\
\hline constant & - & $-3.441^{* * *}$ & 0.336 & - & - & - \\
\hline
\end{tabular}

Coefficient significant at the ${ }^{* * *} 1 \%$-level, ${ }^{* *} 5 \%$-level, ${ }^{*} 10 \%$-level.

a) " $\mathrm{H}_{0}$ : parameters jointly insignificant" is rejected

b) " $\mathrm{H}_{0}$ : no heteroscedasticity" is rejected 
Table 15: Distribution of the marginal effect of the wage sweep-up on the probability of a promotion

Percentiles of marginal effect (percentage points)

5th 25th 50th 75th

Fraction with

\begin{tabular}{llllll}
$-0.791 \%$ & $-0.239 \%$ & $-0.086 \%$ & $-0.027 \%$ & $-0.001 \%$ & 0.038 \\
\hline
\end{tabular}
m. effect $>0$ 
Table 16: Probit regression of internal transfers of personnel

\section{Dependent variable: TRANSFER $\mathrm{t}+\mathbf{1}, \mathbf{1}=$ yes $0=$ no}

\begin{tabular}{|c|c|c|c|c|c|c|}
\hline \multirow{3}{*}{\multicolumn{2}{|c|}{$\begin{array}{c}\text { No. of observations } \\
\text { P-Val. Wald test of joint significance }{ }^{\text {a) }} \\
\text { P-Val. LR test of heteroskedasticity }{ }^{\text {b) }}\end{array}$}} & \multirow{2}{*}{\multicolumn{5}{|c|}{31221}} \\
\hline & & & & & & \\
\hline & & \\
\hline \multicolumn{2}{|c|}{ Sample probability of $y=1$} & \multicolumn{5}{|l|}{$0.60 \%$} \\
\hline \multicolumn{2}{|c|}{ Mean predicted probability of $y=1$} & \multicolumn{5}{|l|}{$0.60 \%$} \\
\hline \multicolumn{2}{|c|}{ Probability of $y=1$ predicted at means } & \multicolumn{5}{|l|}{$0.37 \%$} \\
\hline & \multirow{2}{*}{$\begin{array}{c}\text { Marginal } \\
\text { effect at } \\
\text { means }\end{array}$} & \multicolumn{2}{|c|}{ Mean effect (beta } & \multicolumn{3}{|c|}{ Variance effect (gamma } \\
\hline & & $\begin{array}{l}\text { Coeff. } \\
\text { (beta) }\end{array}$ & $\begin{array}{r}\text { Robust } \\
\text { Std. Dev. }\end{array}$ & $\begin{array}{r}\text { Coeff. } \\
\text { (gamma) }\end{array}$ & & $\begin{array}{l}\text { Robust } \\
\text { td. Dev. }\end{array}$ \\
\hline hourly wage level & $0.007 \%$ & 0.007 & 0.006 & - & - & - \\
\hline wage sweep-up * 100 & $-0.04 \%$ & -0.040 & 0.036 & - & - & - \\
\hline foreign & $-0.1 \%$ & -0.137 & 0.114 & - & - & - \\
\hline male & $-0.2 \%$ & -0.141 & 0.100 & - & - & - \\
\hline schooling & $0.1 \%$ & 0.006 & 0.018 & 0.019 & ** & 0.008 \\
\hline skill training last period & $-2.4 \%$ & $2.663^{* * *}$ & 0.542 & -1.624 & * & 0.931 \\
\hline public sector & $0.2 \%$ & $0.189 * *$ & 0.084 & - & - & - \\
\hline tenure & $-0.01 \%$ & 0.010 & 0.011 & -0.006 & * & 0.003 \\
\hline firm size $>=20<200$ & $-0.1 \%$ & -0.049 & 0.102 & - & - & - \\
\hline firm size $>=200<2000$ & $0.1 \%$ & -0.065 & 0.127 & 0.068 & & 0.046 \\
\hline firm size $>2000$ & $0.6 \%$ & -0.144 & 0.194 & 0.234 & $* \star *$ & 0.059 \\
\hline intermediate status group & $0.0 \%$ & 0.037 & 0.117 & - & - & - \\
\hline high status group & $0.0 \%$ & -0.007 & 0.146 & - & - & - \\
\hline year 1985 & $0.4 \%$ & $0.405 *$ & 0.229 & - & - & - \\
\hline year 1986 & $0.4 \%$ & $0.378^{* *}$ & 0.181 & - & - & - \\
\hline year 1987 & $0.4 \%$ & 0.353 & 0.259 & - & - & . \\
\hline year 1988 & $0.4 \%$ & $0.398 * *$ & 0.195 & - & - & - \\
\hline year 1989 & $0.3 \%$ & 0.275 & 0.204 & - & - & - \\
\hline year 1990 & $0.1 \%$ & 0.083 & 0.185 & - & - & - \\
\hline year 1991 & $0.1 \%$ & 0.132 & 0.192 & - & - & - \\
\hline year 1992 & $0.1 \%$ & 0.093 & 0.191 & - & - & - \\
\hline year 1993 & $-0.3 \%$ & -0.260 & 0.275 & - & - & - \\
\hline year 1994 & $0.2 \%$ & 0.169 & 0.172 & - & - & - \\
\hline year 1996 & $0.1 \%$ & 0.064 & 0.167 & - & - & - \\
\hline year 1997 & $-0.1 \%$ & -0.049 & 0.193 & - & - & - \\
\hline year 1998 & $-0.2 \%$ & -0.168 & 0.218 & - & - & - \\
\hline year 1999 & $0.2 \%$ & 0.199 & 0.162 & - & - & - \\
\hline year 2000 & $-0.1 \%$ & -0.064 & 0.182 & - & - & - \\
\hline year 2001 & $0.2 \%$ & 0.144 & 0.192 & - & - & - \\
\hline year 2002 & $0.1 \%$ & 0.079 & 0.172 & - & - & - \\
\hline constant & - & $-3.479^{* \star *}$ & 0.284 & - & - & - \\
\hline
\end{tabular}

Coefficient significant at the ${ }^{* * *} 1 \%$-level, ${ }^{* *} 5 \%$-level, ${ }^{*} 10 \%$-level.

a) " $\mathrm{H}_{0}$ : parameters jointly insignificant" is rejected

b) " $\mathrm{H}_{0}$ : no heteroscedasticity" is rejected 
Table 17: Probit regression of transfers, robustness check with different sample restrictions

Dependent variable: TRANSFER $t+1,1=y e s$ ono,

Sample restricted to external stayers only

\begin{tabular}{|c|c|c|c|}
\hline \multirow[b]{2}{*}{ Further sample restrictions } & \multicolumn{2}{|c|}{ Effect of wage sweep-up } & \multirow[b]{2}{*}{$\mathrm{N}$} \\
\hline & Coefficient & $\begin{array}{r}\text { Standard } \\
\text { Dev. }\end{array}$ & \\
\hline none & -0.040 & 0.036 & 31221 \\
\hline Female & -0.003 & 0.033 & 9742 \\
\hline Male & -0.036 & 0.035 & 21086 \\
\hline Private sector & 0.015 & 0.082 & 23180 \\
\hline Public sector & $-0.001^{* *}$ & 0.000 & 8041 \\
\hline Age $<30$ & -0.0001 & 0.000 & 4597 \\
\hline $30<=$ Age $<45$ & 0.0003 & 0.001 & 13676 \\
\hline Age $>=45$ & -0.152 & 0.219 & 10552 \\
\hline Tenure $<5$ & 0.009 & 0.069 & 7484 \\
\hline $5<=$ Tenure $<10$ & -0.012 & 0.012 & 7319 \\
\hline Tenure $>=10$ & -0.054 & 0.081 & 15529 \\
\hline Firm size $<20$ & -0.615 & 0.826 & 1772 \\
\hline Firm size $<200$ & 0.010 & 0.041 & 9912 \\
\hline Firm size $>=200$ & -0.00004 & 0.000 & 18489 \\
\hline Firm size $>=2000$ & -0.037 & 0.105 & 10241 \\
\hline West Germany & -0.121 & 0.082 & 27296 \\
\hline East Germany & 0.305 & $\overline{0.201}$ & 3329 \\
\hline Actual hours $<35$ & 0.026 & 0.068 & 1617 \\
\hline Actual hours $>=35$ & -0.046 & 0.048 & 28159 \\
\hline Year $>=1994$ & 0.019 & 0.057 & 19783 \\
\hline Year < 1994 & -0.121 & 0.096 & 11438 \\
\hline
\end{tabular}

Other control variables included as in previous regression.

Coefficient significant at the ${ }^{\star * *} 1 \%$-level, ${ }^{* *} 5 \%$-level, ${ }^{*} 10 \%$ level. 
Table 18: Predicted probabilities of job mobility at different values of wage sweep-up

\begin{tabular}{|c|c|c|c|}
\hline \multicolumn{4}{|c|}{ A) "Average individual" } \\
\hline & $\begin{array}{c}\text { at wage } \\
\text { sweep-up } 2.5 \%\end{array}$ & $\begin{array}{c}\text { at wage } \\
\text { sweep-up } 4 \%\end{array}$ & $\begin{array}{l}\text { Prediction for sample individual with hourly wage }=13 \text {; } \\
\text { foreign }=0 \text {; male }=1 \text {; schooling }=11 \text {; number of skill }\end{array}$ \\
\hline Quit & $0.65 \%$ & $0.57 \%$ & trainings $=1$; skill training last period $=0$; tenure $=12$; \\
\hline Layoff & $1.02 \%$ & $0.49 \%$ & fsize $=>2000$; number external moves $=1$; public sector $=0$; \\
\hline Promotion & $1.78 \%$ & $1.38 \%$ & $\begin{array}{l}\text { intermediate status group }=1 \text {; year }=2002 \text {; } \\
\text { sector=manufacturing. }\end{array}$ \\
\hline
\end{tabular}

\begin{tabular}{|c|c|c|c|}
\hline \multicolumn{4}{|c|}{ B) "Loose labour market ties" } \\
\hline & $\begin{array}{c}\text { at wage } \\
\text { sweep-up } 2.5 \%\end{array}$ & $\begin{array}{c}\text { at wage } \\
\text { sweep-up } 4 \%\end{array}$ & \multirow{4}{*}{$\begin{array}{l}\text { Prediction for sample individual with hourly wage }=5 \text {; } \\
\text { foreign }=1 \text {; male=0; schooling }=8 \text {; number of skill trainings }=0 \text {; } \\
\text { skill training last period=0; tenure }=2 \text {; fsize }>20<200 \text {; number } \\
\text { external moves }=5 \text {; public sector }=0 \text {; low status group }=1 \text {; } \\
\text { year }=2002 \text {; sector=services. }\end{array}$} \\
\hline Quit & $3.87 \%$ & $3.45 \%$ & \\
\hline Layoff & $11.21 \%$ & $9.29 \%$ & \\
\hline Promotion & $0.05 \%$ & $0.04 \%$ & \\
\hline
\end{tabular}

\begin{tabular}{lccl}
\hline C) "Strong labour market ties" & & \\
& at wage & at wage & Prediction for sample individual with hourly wage=25; \\
& sweep-up 2.5\% & sweep-up 4\% & $\begin{array}{l}\text { Predign=0; male=1; schooling=18; number of skill } \\
\text { foreign=0; }\end{array}$ \\
Quit & $0.42 \%$ & $0.38 \%$ & trainings=3; skill training last period=0; tenure=20; \\
Layoff & $0.005 \%$ & $0.001 \%$ & fsize=>2000; number external moves=1; public sector=0; \\
Promotion & $2.45 \%$ & $2.12 \%$ & high status group=1; year=2002; sector=credit \& insurance. \\
\hline \hline
\end{tabular}

\section{D) "Strong labour market ties \& upskilling last period"}

\begin{tabular}{|c|c|c|c|}
\hline & $\begin{array}{c}\text { at wage } \\
\text { sweep-up } 2.5 \%\end{array}$ & $\begin{array}{c}\text { at wage } \\
\text { sweep-up } 4 \%\end{array}$ & \\
\hline Quit & $0.42 \%$ & $0.38 \%$ & Prediction for sample individual as in case $\mathrm{C}$, but skill \\
\hline Layoff & $0.005 \%$ & $0.001 \%$ & training last period $=1$. \\
\hline Promotion & $8.42 \%$ & $8.87 \%$ & \\
\hline
\end{tabular}


Table 19: Extent of wage rigidity: results and comparison to the literature

\begin{tabular}{|c|c|c|c|c|}
\hline & This study & $\begin{array}{l}\text { Pfeiffer } \\
\text { (2003a) }\end{array}$ & $\begin{array}{l}\text { Bauer, Bonin } \\
\text { and Sunde } \\
\text { (2003) }\end{array}$ & $\begin{array}{l}\text { Knoppik and } \\
\text { Beissinger } \\
(2003)\end{array}$ \\
\hline data set & GSOEP & IABS & IABS & IABS \\
\hline observation period & $1986-2002$ & 1976-1995 & $1976-1997$ & $1976-1995$ \\
\hline results refer to & $\begin{array}{l}\text { stayers and } \\
\text { movers }\end{array}$ & stayers $^{\mathrm{g})}$ & stayers & stayers \\
\hline wage sweep-up & $3.3 \%$ & $6.0 \%{ }^{d)}$ & $2.18 \%{ }^{c)}$ & - \\
\hline real & $3.25 \%$ & $5.0 \%{ }^{e)}$ & $1.90 \%{ }^{c)}$ & - \\
\hline nominal & $0.05 \%$ & $1.0 \%{ }^{\mathrm{e})}$ & $0.28 \%{ }^{c)}$ & $0.08 \% / 0.12 \%{ }^{b)}$ \\
\hline notional wage growth & $1.4 \%$ & $-0.3 \%{ }^{f)}$ & $2.40 \%{ }^{c)}$ & $1.76-2.09 \%{ }^{h)}$ \\
\hline pr & 0.47 & $0.7^{\mathrm{e})}$ & $0.50^{c)}$ & \\
\hline pn & 0.006 & - & $0.17^{c)}$ & \\
\hline affected real & 0.259 & $0.46^{\mathrm{e})}$ & $0.3^{c)}$ & \\
\hline affected nom & 0.003 & $0.069^{\mathrm{e})}$ & $0.06^{c)}$ & $0.056-0.073^{b)}$ \\
\hline
\end{tabular}

a) The study of Knoppik and Beissinger (2003) models nominal wage rigidity only. Their results reported here refer to the mixed measurement error specifications.

b) Salary earners / wage earners. Results refer to CMME specification in their table 3.

c) Non-weighted averages from their tables 3 and 4 . Values for real rigidity exhibit a strong decline in the study of Bauer, Bonin and Sunde. Between 1976 and 1997 the fraction of workers affected by real wage rigidity declines from around 0.4 to 0.16 , and the wage sweep-up correspondingly declines from $3.3 \%$ to $1 \%$.

d) see Pfeiffer (2003a) page 201.

e) Non-weighted average of values in table 6.3 in Pfeiffer (2003a)

f) Non-weighted average of annual mean notional wage growth in figure 6.6 in Pfeiffer (2003a)

g) Here, we report Pfeiffer's (2003a, table 6.3) results for stayers only. As our analysis includes movers as well, results would be more comparable if we took an average of Pfeiffer's results for stayers (wage sweep-up $6 \%$ ) and movers (wage sweep-up 2.5), which would reduce the extent of wage rigidity he measured. However, it would not be reduced by much as stayers represent under $10 \%$ of his sample (Pfeiffer 2003a, table 2.3). An approximate calculation indicates that it would reduce aggregate wage sweepup from $6 \%$ to $5.7 \%\left(6^{\star} 0.9+2.5^{\star} 0.1\right)=5.7$.

h) See Knoppik and Beissinger (2003), footnote 12. 
Figure 1: Performance of ML estimates of the wage rigidity model versus the linear regression model approximated by the observed wage change distribution in 1996
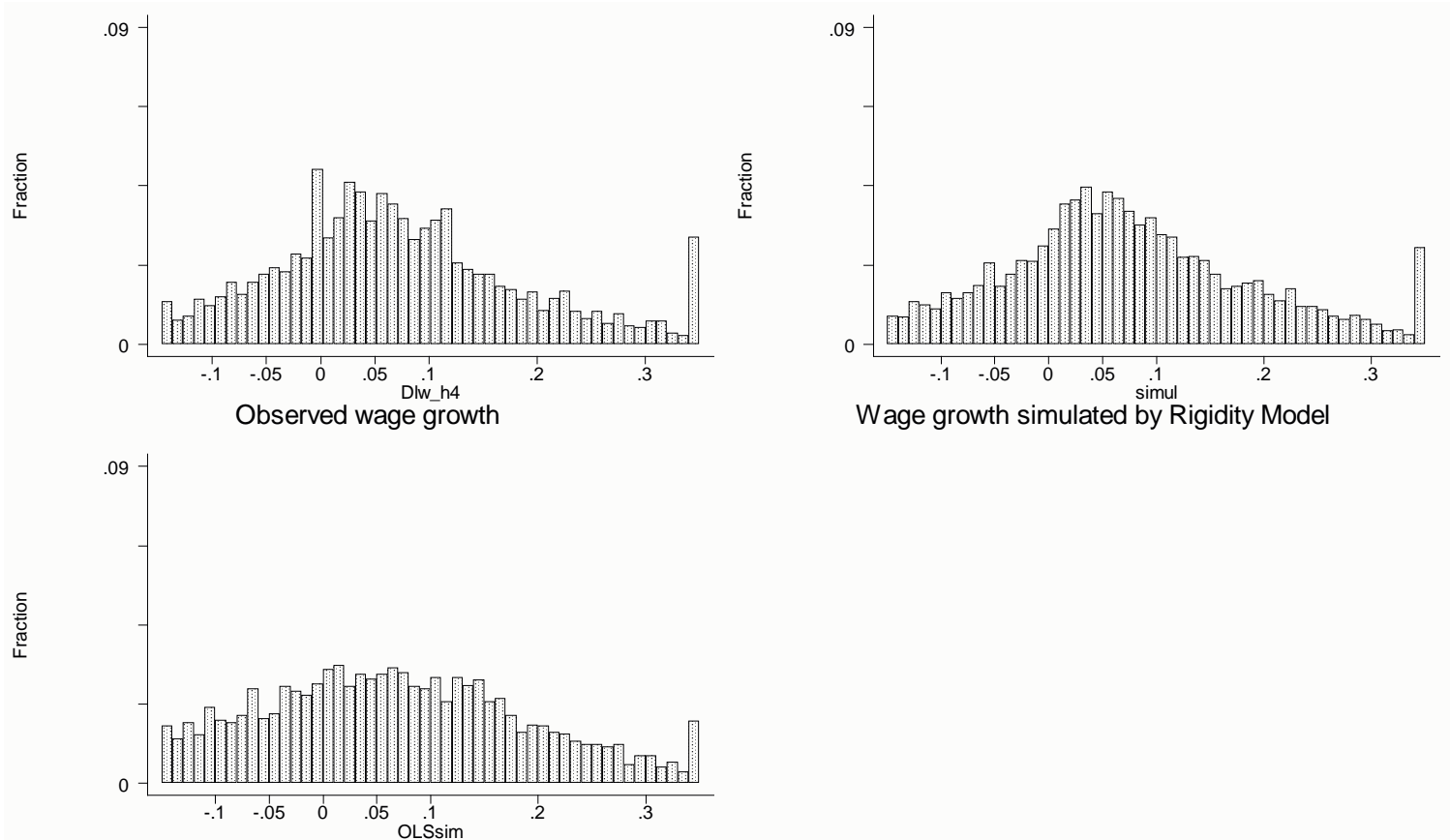

Wage growth simulated by Linear Regression Model

Year:1996 